\title{
Automatic classification of the highveld grassland of Lichtenburg, south-western Transvaal*
}

\author{
J. W. MORRIS $\dagger$
}

\section{ABSTRACT}

A quantative, semi-detailed plant ecological study of the area between $25^{\circ} 54^{\prime}$ and $26^{\circ} 22^{\prime} \mathrm{E}$ and $26^{\circ} 00^{\prime}$ and $26^{\circ} 20^{\prime} \mathrm{S}$, situated around the town of Lichtenburg in the south-western Transvaal, Sous $\mathrm{n}$ Africa, is reported. Mean annual temperature of the study area is $17^{\circ} \mathrm{C}$ and annual rainfall is about $600 \mathrm{~mm}$. A basic difference is recognised between the Bankenveld Land System and the CT Grassland Land System. The former is underlain by dolomite with lithosolic soils, Bankenveld vegetation and cattle ranching as the chief jard-use, whereas the latter is underlain by granite, Ventersdorp lavas, Dwyka tillite and surface limestone with Shorrozks, Mangano and Lichtenburg series soils, Cymbopogon-Themeda Veld vegetation and extensive cultivation of maize as the chief land-use. One hundred and ten $16 \mathrm{~m}^{2}$ quadrats were placed within each Land System by means of a stratified-random strategy. Of the 247 species encountered, nearly 100 occurred in less than six quadrats. Themeda triandra, Aristida congesta, Elionurus argenteus, Anthospermum rigidum and Justicia anagaloides were common throughout. Two association analyses were carried out and 15 final groups were interpreted out of a total of 21 groups.

\section{RESUME}

CLASSIFICATION QUANTITATIVE DE LA PRAIRIE DE IIAUTES TERRES DE LICIITENBURG, SUD-OUEST DU TRANSVAAL

On expose les résultats d'une étude phyto-écologique quantitative et semi-détaillée de la région comprise entre $25^{\circ} 54^{\prime}$ et $26^{\circ} 22^{\prime}$ E. et $26^{\circ} 00$ et $26^{\circ} 20^{\prime}$ S., autour de la villo de Lichtenburg dans le sudouest du Transiaal, Afrique du Sud. La moyenne annuelle de la temperature y est de $17^{\circ} \mathrm{C}$ et la hauteur de pluie d'environ $600 \mathrm{~mm}$. On reconnait une différence fondamentale entre le Bankenveld Land System et le CT Grassland Land System. Le premier est supporté par de la dolomite avec des lithosols, une végétation du type Bankenveld et l'élevage du bétail constituant la principale utilisation du terrain: tandis qu'au second sont sousjacents du granite, des laves de Ventersdorp, de la tillite de Dwyka et des calcaires de surface avec des sols des séries de Shorrocks, Mangano et Lichtenburg sur lesquels pousse une végétation de prairie à Cymbopogon-Themeda et dont la principale utilisation est la culture extensive du mais. Cent et dix carrés de $16 \mathrm{~m}$ de côté ont été répartis sur chaque sistème selon la technique de stratification aléatoire. Des 247 espèces rencontrées, près de 100 ont été trouvées sur moins de six carrés. Themeda triandra, Aristida congesta, Elionurus argenteus, Anthospermum rigidum et Justicia anagaloides étaient communes partout. Deux analyses d'association ont été exécutées et d'un total de 21 groupes. 15 groupes finals ont été interprétés.

\section{CONTENTS}

Introduction

1. Description of study area.............

1.1 Location....................

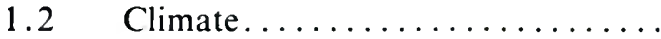

Geomorphology and geology.......

Soils.......................

Vegetation...................

Land-use.....................

CT Grassland and Bankenveld Land Systems....................

Procedures used in this study.........

Sampling strategy.............

Association analysis.............

Presence and indicator value.......

Re-allocation.................

Classification of the vegetation by association analysis..........

Summary statistics of data........

Total association analysis.........

Bankenveld association analysis....

3.3

4.

4. 1

Discussion and conclusions.........

Sampling strategy............

Methodological aspects...........

Vegetational aspects............

Acknowledgements................ Uittreksel.

References...................

Page

267

268

268

268

270

271

272

273

274

274

274

274

276

276

276

276

276

282

289

289

289

290

290

291

291

* Forms part of a Ph.D thesis submitted to the University of Natal (Morris, 1973).

$\dagger$ Botanical Research Institute, Department of Agricultural Technical Services, Private Bag X101, Pretoria.

\section{INTRODUCTION}

The overall model for the ecological survey of the natural and semi-natural vegetation of the Highveld Agricultural Region of South Africa was designed by D. Edwards and J. C. Scheepers of the Botanical Research Institute. At an early stage, they decided that instead of spreading surveying efforts equally over the whole Region of approximately 11655000 ha, the Key Area approach, whereby efforts would initially be concentrated in the Lichtenburg, Maquassie, Kroonstad, Bethlehem and Villiers Key Areas, would be used. Each Key Area is a quarter degree square in extent and covers approximately 69000 ha. Individual surveys of these five areas would be followed by extrapolatory surveys linking the areas. The aim of the survey reported here, a contribution towards the Highveld Region survey, was an account of the plant ecology of the Lichtenburg Key Area. A report on the Kroonstad and Bethlehem Areas (Scheepers, 1975) has already been produced.

The basic sampling strategy of 4 by $4 \mathrm{~m}$ quadrats, with a stratified-random distribution, was chosen during preliminary studies for the Kroonstad Area and the Lichtenburg and Bethlehem surveys followed suit to aid later comparison and extrapolation. The technique of association analysis was chosen to synthesize the results of each survey.

Two Land Systems (Dowling, 1968; Mabbutt, 1968) occur in the Lichtenburg Key Area. In this communication they are referred to. for convenience and brevity, as CT Grassland and Bankenveld Land Systems. The former includes Dry CymbopogonThemeda Veld and Sandy Cimbopogon-Themeda Veld and the latter covers part of Bankenveld (Acocks, 1953). The main features of and differences between the two Land Systems are detailed later. Briefly, Bankenveld lies on an area of dolomitic lithosol 
north of Lichtenburg where a great deal of the naturai and semi-natural vegetation (physiognomically a grassland) remains and the main land-use activity is cattle and sheep farming. CT Grassland is an extensively-cultivated area south, east and west of Lichtenburg where maize is the chief crop. Natural and semi-natural vegetation is rare but, where still encountered, the physiognomic structure is grassland or savanna. In general, it is only small rock outcrops and poorly-drained areas which are not ploughed in the CT Grassland Land System.

\section{DESCRIPTION OF STUDY AREA}

\subsection{Location}

The location of the study area and its position relative to towns in the South-western Transvaal, South Africa are indicated in Fig. 1. Lichtenburg is the only town situated in the area. Initially, the area for study was the 2626A A quarter degree square but as parts were extensively cultivated the area was enlarged, as illustrated in Fig. 1, to enable placement of enough sampling points in relatively undisturbed vegetation. A rectangular shape was retained even though much of the enlarged area was not sampled.
The quarter degree square covers about 69000 ha and the whole study area about 177000 ha.

\subsection{Climate}

Apart from precipitation and air temperature records, no climatic data are available from within the study area. Data from Potchefstroom, and even Pretoria, are used to complete the description of climate given below. Where data from outside the study area are used, they are intended as indications of conditions prevailing within the area and no more.

\subsubsection{Radiation and sunshine}

Few meteorological stations in South Africa record radiation. The station nearest to Lichtenburg is at Pretoria, half a degree further north and $200 \mathrm{~km}$ east. The instrument at Pretoria is a Kipp solarimeter and all measurements are from a horizontal surface. The percentage radiation received at the top of the atmosphere, but not reaching the surface of the earth at Pretoria, averages 39 percent annually with a maximum attenuation of 45 percent in December and minimum of 31 percent in June (Schulze, 1965).

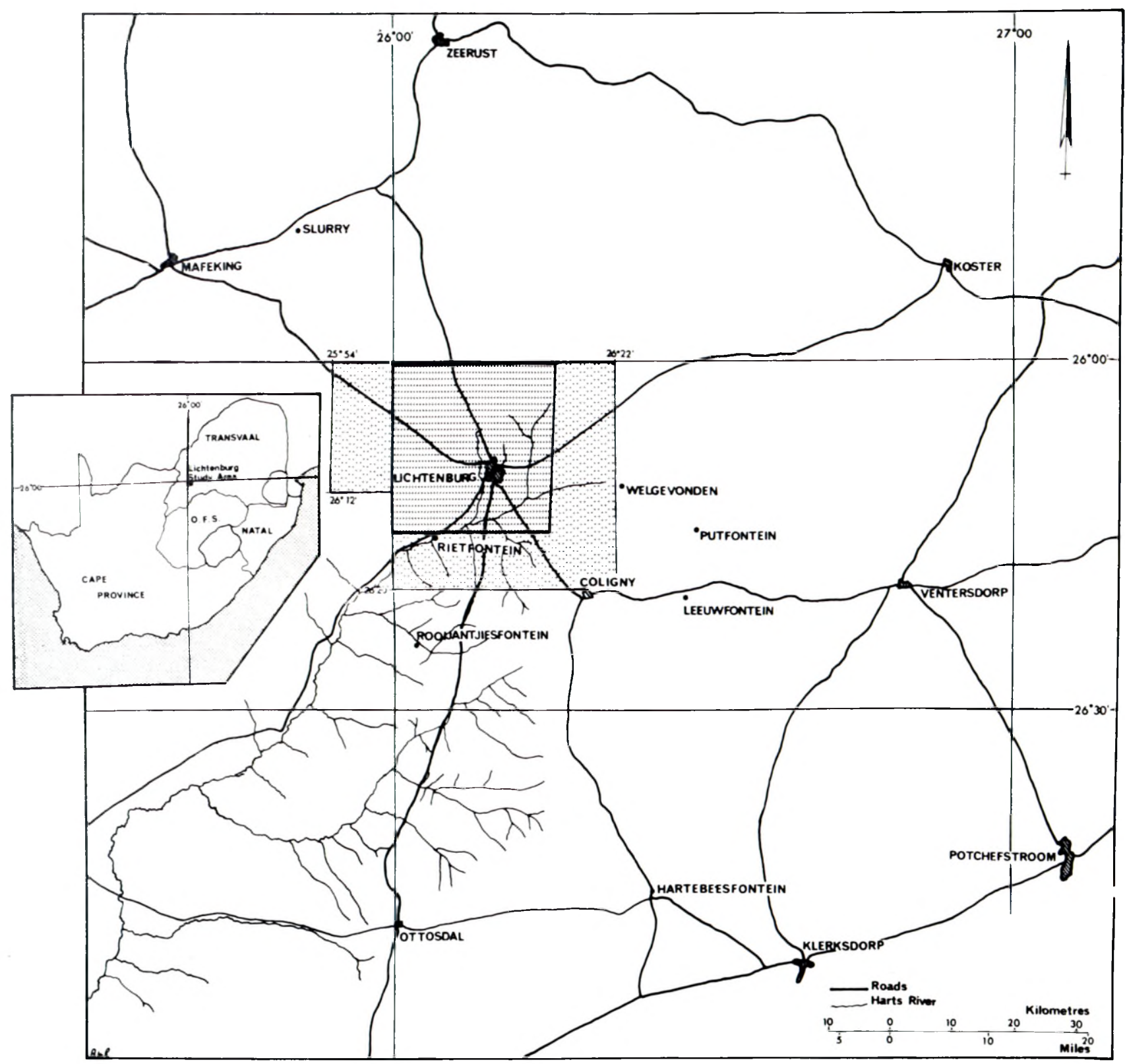

FIG. 1.--Locality of study area. Dark shading indicates 2626AA quarter degree square and lighter shading the enlarged study area. Inset: position in South Africa. 
The monthly march of radiation at Pretoria is given by Weather Bureau (1968). The highest mean daily sums occur in summer from October to February when the global radiation exceeds $530 \mathrm{cal} / \mathrm{cm}^{2} /$ day and the lowest mean daily sums in June and July (less than $360 \mathrm{cal} / \mathrm{cm}^{2} /$ day). Radiation increases sharply from July to September and then stays fairly constant during summer before starting to decrease in February. The levelling off of radiation in summer is due to an increase in cloudiness compensating for radiation increases during this season. Diffuse radiation varies from over $150 \mathrm{cal} / \mathrm{cm}^{2} /$ day in summer to less than $80 \mathrm{cal} / \mathrm{cm}^{2} /$ day in winter. The highest sum of radiation recorded on a single day $\left(800 \mathrm{cal} / \mathrm{cm}^{2}\right)$ occurred during the month of January and the lowest (27 cal $/ \mathrm{cm}^{2}$ ) during July (Schulze, 1965).

\subsubsection{Air temperature}

Although air temperature data have been recorded at Lichtenburg since 1905, observations until 1950 are the most recently published statistics (Weather Bureau, 1954). During that period the mean of daily maximum temperature varied from over $28{ }^{\circ} \mathrm{C}$ in December and January to under $20{ }^{\circ} \mathrm{C}$ in June and July. Mean of daily minimum was about $15{ }^{\circ} \mathrm{C}$ in January and February and less than $2{ }^{\circ} \mathrm{C}$ in June and July. Of more interest ecologically are the extreme maxima and minima (Walter \& Leith, 1960). Extreme maximum temperatures in summer (September to February) exceed $35^{\circ} \mathrm{C}$ while in winter the maximum recorded temperatures exceed $25{ }^{\circ} \mathrm{C}$ (July). Extreme minima below $-5^{\circ} \mathrm{C}$ occur from May to August. In mid-summer (December to February) the extreme minimum temperature is above $3{ }^{\circ} \mathrm{C}$.

\subsubsection{Grass minimum temperature and frost}

Mean grass minimum temperature at Potchefstroom (Schulze, 1965) varies from $11^{\circ} \mathrm{C}$ in December, January and February to below $-5{ }^{\circ} \mathrm{C}$ in June and July. The maximum exceeds $16{ }^{\circ} \mathrm{C}$ from November to March and drops to $8{ }^{\circ} \mathrm{C}$ in July while the minimum temperatures throughout the year (except February) are below $1{ }^{\circ} \mathrm{C}$. The extreme minimum of $-17{ }^{\circ} \mathrm{C}$ was recorded during July.

In the absence of observations on frost occurrence, climatologists have used various air temperatures to indicate the occurrence of frost. If the criteria of the publication Weather Bureau (1954), namely a minimum temperature less than $0{ }^{\circ} \mathrm{C}$ in a Stevenson screen 1,2 $\mathrm{m}$ above the surface, are accepted, Lichtenburg averages 106 days per annum (30-year records) with a possibility of experiencing frost. The average first date is 19th May and the average last date is 2 nd September. As the average number of days on which frost actually occurs is 26 . frost may be expected one night in four from the middle of May until the end of August. The extreme first date was 16th April and the extreme last date on which frost has been recorded was 26th September.

\subsubsection{Soil temperature}

Soil temperatures have been recorded at Potchefstroom for five years (Schulze, 1965). The highest monthly mean temperatures have been recorded at 1400 hours in November, December, January and February when the temperature exceeded $29{ }^{\circ} \mathrm{C}$ at $10 \mathrm{~cm}$ and $24^{\circ} \mathrm{C}$ at $20 \mathrm{~cm}$. The lowest temperatures (0800 hours) in June and July at these depths, where most plant roots are located, were $8,3{ }^{\circ} \mathrm{C}$ at $10 \mathrm{~cm}$ and $10,2{ }^{\circ} \mathrm{C}$ at $20 \mathrm{~cm}$.

\subsubsection{Surface wind}

No information on surface wind is available from within the study area but the general features may be determined from a knowledge of air circulation patterns over South Africa and from observations of wind speed and direction at nearby meteorological stations. In general, there seems to be little seasonal change in wind direction or force. Winds with a northerly component predominate, but it is difficult to assign any one prevailing direction according to Schulze (1965). The northerly component results from the normal anticyclonic circulation of air around a high pressure cell located over the interior of South Africa throughout the year.

TABLE 1.- Mean monthly rainfall in $\mathrm{mm}(\mathrm{r})$ and mean number of days with rain (d) at the seven stations with recording pariods of over 20 years from Weather Bureau (1965)

\begin{tabular}{|c|c|c|c|c|c|c|c|}
\hline $\begin{array}{l}\text { Station name } \\
\text { and period } \\
\text { (in years) }\end{array}$ & $\begin{array}{l}\text { Rietfontein } \\
\quad(28)\end{array}$ & $\begin{array}{l}\text { Rooijantjies- } \\
\text { fontein (31) }\end{array}$ & $\begin{array}{l}\text { Lichtenburg } \\
\text { TNK (57) }\end{array}$ & $\begin{array}{l}\text { Lichtenburg } \\
\text { MUN (56) }\end{array}$ & $\begin{array}{l}\text { Leeuwfontein } \\
\text { (36) }\end{array}$ & $\begin{array}{l}\text { Welgevonden } \\
\text { (34) }\end{array}$ & $\begin{array}{l}\text { Putfontein } \\
\text { (31) }\end{array}$ \\
\hline 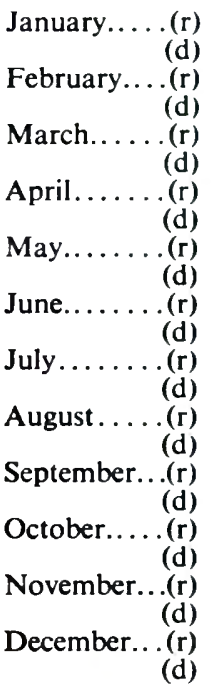 & $\begin{array}{c}105,3 \\
10 \\
104,3 \\
9 \\
91,5 \\
9 \\
45,9 \\
5 \\
20,8 \\
3 \\
10,6 \\
1 \\
5,7 \\
1 \\
6,0 \\
1 \\
14,7 \\
2 \\
53,6 \\
6 \\
69,4 \\
8 \\
97,0 \\
9\end{array}$ & $\begin{array}{c}101,2 \\
10 \\
105,4 \\
9 \\
80,4 \\
9 \\
49,5 \\
5 \\
19,7 \\
3 \\
9,4 \\
1 \\
4,7 \\
1 \\
5,6 \\
1 \\
12,3 \\
2 \\
42,5 \\
5 \\
68,5 \\
8 \\
88,3 \\
9\end{array}$ & $\begin{array}{c}109,4 \\
10 \\
92,2 \\
9 \\
92,9 \\
9 \\
38,7 \\
5 \\
17,7 \\
3 \\
6,4 \\
1 \\
6,5 \\
1 \\
5,1 \\
1 \\
15,0 \\
2 \\
46,2 \\
5 \\
73,4 \\
8 \\
98,4 \\
10\end{array}$ & $\begin{array}{c}112,3 \\
10 \\
96,5 \\
8 \\
94,0 \\
8 \\
36,5 \\
4 \\
18,0 \\
1 \\
6,9 \\
1 \\
6,1 \\
1 \\
6,0 \\
1 \\
14,8 \\
1 \\
45,6 \\
5 \\
69,0 \\
7 \\
95,2 \\
9\end{array}$ & $\begin{array}{c}104,5 \\
8 \\
89,8 \\
7 \\
93,4 \\
7 \\
41,6 \\
4 \\
21,2 \\
2 \\
5,9 \\
1 \\
6,5 \\
1 \\
2,4 \\
1 \\
14,3 \\
1 \\
40,4 \\
5 \\
66,8 \\
6 \\
99,2 \\
8\end{array}$ & $\begin{array}{c}99,7 \\
6 \\
91,4 \\
6 \\
86,7 \\
6 \\
31,7 \\
2 \\
16,8 \\
1 \\
7,2 \\
1 \\
3,7 \\
1 \\
1,9 \\
1 \\
15,5 \\
11 \\
41,2 \\
4 \\
71,4 \\
5 \\
80,9 \\
5\end{array}$ & $\begin{array}{c}109,5 \\
10 \\
93,2 \\
8 \\
83,6 \\
9 \\
31,5 \\
4 \\
13,4 \\
3 \\
2,8 \\
1 \\
6,6 \\
1 \\
6,1 \\
1 \\
12,7 \\
2 \\
39,9 \\
4 \\
64,3 \\
7 \\
87,4 \\
9\end{array}$ \\
\hline $\begin{array}{r}\text { Year...... (r) } \\
\text { (d) }\end{array}$ & 624,8 & 587,5 & 601,9 & $\begin{array}{l}600,9 \\
56\end{array}$ & $\begin{array}{l}586,0 \\
51\end{array}$ & $\begin{array}{c}548,1 \\
39\end{array}$ & $\begin{array}{c}551,0 \\
59\end{array}$ \\
\hline
\end{tabular}




\subsubsection{Precipitation}

Precipitation within and near the study area is almost entirely in the form of rain, most of which falls during summer. While severe hail storms are experienced with a fairly high frequency, snow is rare. Data from a number of meteorological stations measuring rainfall within the study area are given in Table 1. Mean annual rainfall at Lichtenburg is just over $600 \mathrm{~mm}$, with 85 percent falling during the six summer months from October to March. Rain may be expected to fall on ten days each month during December and January and on only one day per month in winter (Table 1), with an average of about 60 days per year.

\subsubsection{Climate classification and summary}

According to Schulze (1947), the Lichtenburg study area is in the BSkw class of Köppen. The climate is arid (steppe), cold and dry with a mean annual temperature below $18{ }^{\circ} \mathrm{C}$. Mean temperature of the hottest month exceeds $18{ }^{\circ} \mathrm{C}$ and the dry season is during winter. Following the Thornthwaite classification (Schulze, 1947; 1958), the study area lies on the border between DB'd to the west and $\mathrm{CB}^{\prime} \mathrm{d}$ to the east. DB'd is a semi-arid warm (steppe) climate and CB'd is subhumid warm. In both climates, moisture is deficient throughout the year. Following the classification of UNESCO-FAO (1963) the climate is accentuated temperate tropical. In other words, there is a dry period of between one and eight months coinciding with the period of shortest day-length, the mean temperature of the coldest month is between $0{ }^{\circ} \mathrm{C}$ and $10{ }^{\circ} \mathrm{C}$ and the xerothermic index is between 150 and 200.

The climate of the study area is summarized in Fig. 2 (modified after Walter \& Leith, 1960) and is described by Schulze (1965), on which the following description is based. The average daily maximum temperature is about $28{ }^{\circ} \mathrm{C}$ in January and $18{ }^{\circ} \mathrm{C}$ in July but in extreme cases temperatures may rise to $37{ }^{\circ} \mathrm{C}$ and $25{ }^{\circ} \mathrm{C}$, respectively. Average daily minima range from about $15^{\circ} \mathrm{C}$ in January to $2{ }^{\circ} \mathrm{C}$ in July, whereas extremes may drop to $6{ }^{\circ} \mathrm{C}$ and $-10{ }^{\circ} \mathrm{C}$,

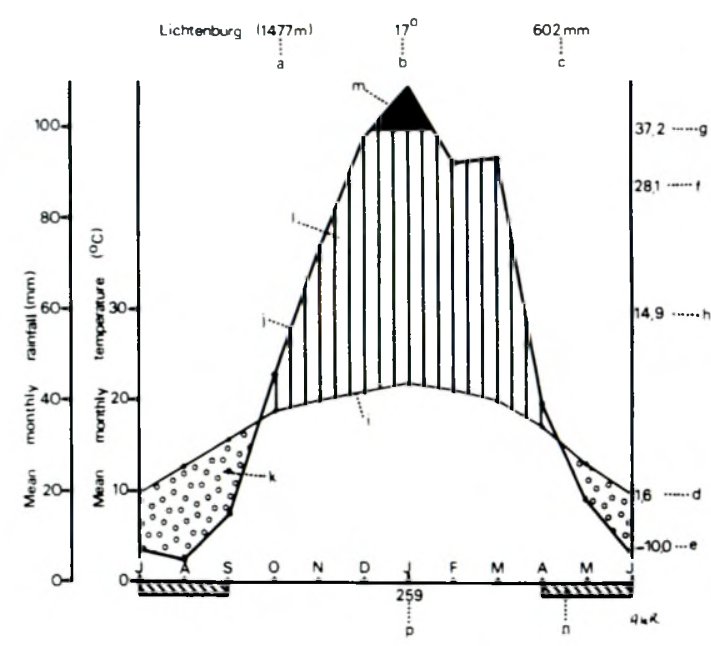

FIG. 2.-Climate diagram for Lichtenburg $(\mathrm{a}=$ altitude, $\mathrm{b}=$ mean annual temperature, $\mathrm{c}=$ mean annual precipitation, $\mathrm{d}=$ mean daily minimum temperature of coldest month, $\mathrm{e}=$ absolute minimum temperature, $\mathrm{f}=$ mean daily maximum temperature of hottest month, $\mathrm{g}=$ absolute maximum temperature, $\mathrm{h}=$ mean range of temperature, $\mathrm{i}=$ curve of mean monthly temperature, $j=$ curve of mean monthly precipitation, $\mathrm{k}=$ dry season, $\mathrm{l}=$ wet season, $\mathrm{m}=$ mean monthly precipitation over $100 \mathrm{~mm}, \mathrm{n}=$ months with absolute daily minimum temperature below $0^{\circ} \mathrm{C}, \mathrm{p}=$ mean duration of frost-free period in days). respectively. The period during which frost is likely to occur lasts, on average, for 106 days from May to September, during which period frost occurs on about 26 days. Sunshine duration in summer is about 60 percent and in winter 80 percent of the possible.

Mean annual precipitation is about $60 \mathrm{~J} \mathrm{~mm}$. Rainfall is almost exclusively due to showers and thunderstorms. Winter months are normally dry and about 85 percent of the annual presipitation falls during the summer months from Oztober to March. A small rainfall peak occurs in January. Heavy falls of $125 \mathrm{~mm}$ to $150 \mathrm{~mm}$ are occasionally recorded in a few hours. The average annual number of thunderstorms is about 75. These storms are often violent with severe lightning and strong, but short-lived, gusty, south-westerly winds and are sometimes accompanied by hail. The area has a high hail frequency with an average of four to seven occurrences annually.

\subsection{Geomorphology and geology}

\subsubsection{Relief}

The study area lies between $1460 \mathrm{~m}$ and $1520 \mathrm{~m}$ above sea level. It consists of a large, undulating plain characterised by the absence of any marked topographical features. Gentle rises and shallow hollows throughout, and shallow valleys of the Harts River and its tributaries in the south are the most noteworthy topographical features.

Even in this very monotonous landscape a clear relationship between topography and geology is evident. The south-eastern corner is underlain by by Archaean granite, which forms dome-shaped hills. This slightly-raised portion is part of the divide between the Harts River to the west and Schoon Spruit in the east. The area occupied by Ventersdorp lava, south and south-east of Lichtenburg, is usually devoid of physiographic features. Volcanic brecshia appears in dome-shaped outcrops and volcanic tuff usually forms a featureless topography. The area covered by dolomite, to the north of Lichtenburg, is very flat, being relieved by occasional chert ridges, shallow depressions, dry watercourses and, more frequently, by sink-holes. Surface limestone, west of Lichtenburg, builds extensive flat plains.

\subsubsection{Geological strata}

The geology of the area has been described by Von Backström et al. (1953), on which the following account is based.

Although Archaean granite occurs south-east of Lichtenburg, outcrops are rare. It is usually overlain by sandy surface drift.

Deposits of the Ventersdorp system are found in a belt along the southern edge of the area from the south-western corner to a point south of Lichtenburg and then occur again along the eastern boundary of the area. The system consists mainly of andesitic lava. Intercalated are agglomerate and volcanic conglomerate, pyroclastic sediments or tuff and clastic sediments including boulder conglomerate.

Rocks of the Dolomite series of the Transvaal system are, for the most part, covered by more recent deposits, particularly of gravel and surface limestone. Small outcrops occur north and north-east of Lichtenburg, on the boundary of the study area. The Dolomite series consists mainly of blue-grey, massive, dolomitic limestone, with intercalated lenses and layers of chert and shale, the latter being developed more particularly near the base of the Series. In many places dolomite has been weathered chemically and numerous sink-holes are found as a result. 
Dwyka series tillite and shale of the Karoo system occur over a fairly wide area south and east of Lichtenburg. Owing to fast weathering and the softness of the formation, rocks are seldom exposed at the surface. Tillite is composed of a soft, clayey, unstratified matrix in which unsorted fragments are spread at random. The fragments are mostly of chert and various quartzites. Examples of glaciated pavements and other distinct signs of glaciation are found.

Economically, the Tertiary and recent deposits are the most important in the area. They consist of gravel, surface limestone, sand and alluvium.

Gravel is found mainly overlying Dolomite series rocks in a belt along the northern edge of the area. The deposits, which vary in depth from a few centimetres to over $50 \mathrm{~m}$, are made up of rounded alluvial material with which is mixed angular, eluvial chert. The alluvial material consists mainly of white, cream-coloured or light grey pebbles of chert and chalcedony although a variety of pebbles derived from other geological systems are also encountered. The eluvial material is composed of angular and irregularly-shaped fragments of chert and concretionary grains of iron, or manganese-iron, derived from weathering of the dolomite floor. Dolomite series rock includes a proportion of very hard, white or grey chert in layers, lenses and veins. As the matrix is dissolved by chemical action, chert remains behind as angular rubble.

Surface limestone covers a large area west of Lichtenburg. It is not generally exposed at the surface, but is covered by a thin, sandy, overburden usually from $20 \mathrm{~cm}$ to one metre thick. The thickness of the limestone itself is difficult to determine but it is known to occur as a thin, hard, crust although it is usually much thicker. Depths between $10 \mathrm{~m}$ and $38 \mathrm{~m}$ have been recorded. The quality of the limestone varies from some of great purity to some that can be described as calcrete. At the surface, the limestone is usually hard and massive while at greater depths it is softer, granular, friable and slightly stratified.

In the area north-west of Lichtenburg the older formations are overlain by red and yellowish Kalahari sand, consisting in the main of slightly rounded grains of quartz, less than one $\mathrm{mm}$ in diameter. South-east of Lichtenburg. coarse-grained sand covers a fairly extensive area. It consists of subangular grains of quartz and felspar with flakes of mica and is mainly derived from underlying Archaean granite.

\subsubsection{Erosion surfaces}

Erosion surfaces of the Highveld Agricultural Region have been mapped by Harmse (1967). Dolomite, and gravels overlying dolomite, north of Lichtenburg are of the Karst structural phase of the African surface. Sand overlying the rest of the study area is of the aggradational phase (aeolian sand) of the African surface. Sand was transported from the north-west.

\subsubsection{Economic geology}

As the surface mining of diamonds and limestone within the study area influence the natural vegetation, these activities are described briefly.

The first diamond in the Lichtenburg district was discovered during 1921, although diamonds were being mined in the South-western Transvaal before 1914 (Wagner, 1914; Du Toit, 1951; Draper, 1928; Williams, 1930). As diamond discoveries increased at Lichtenburg, more and more fortune hunters arrived and many spectacular 'rushes' were held, culminating in the famous 'charge' on the farm Grasfontein in March. 1927 when some 25000 runners participated. In August, 1926, an estimated 56000 non-Europeans were employed. According to Williams (1930), a population of over 100000 was resident on the new diamond fields shortly after their discovery. The presence of this large population, concentrated in a small area north of Lichtenburg, must have had a marked effect on the natural vegetation. In addition to direct disturbance by trampling, digging and clearing, the keeping of livestock, gathering of firewood and cultivation of crops probably caused rapid deterioration of vegetation near the diggings. Very little activity is evident on the diggings now and only an occasional miner is encountered.

A large proportion of the area underlain by surface limestone has been purchased by two cement companies with factories in the area. The thin, sandy overburden is bulldozed away and surface limestone is mined by open-cast methods.

\subsection{Soils}

Soils of the 2626AA quarter degree square have been described and mapped by Van der Bank (1958). His map of 17 soil series, four soil complexes and three land classes has been simplified in collaboration with E. Verster (pers. comm.) to eight soil series to conform with present soil nomenclatural concepts of the Soils and Irrigation Research Institute, Pretoria.

The soil survey by Van der Bank (1968) clearly illustrates from one side the differences in emphasis placed by pedologists and plant ecologists in the same area. He describes, in detail, soils which are under heavy cultivation while the Dolomite lithosol receives scant mention. To the botanist, on the other hand, the natural vegetation of the ploughed area is solely of historical interest while the vegetation of the unploughed areas (the lithosols) has great economic and academic value. These differences in emphasis naturally hinder close correlation between results of these and other soil and vegetation surveys of the same area.

\subsubsection{Shorrocks, Mangano and Lichtenburg Series}

Shorrocks series soils occur in small patches northwest of Lichtenburg. Mangano series soils occur very locally within the Dolomite region north of Lichtenburg, while Lichtenburg series soils cover relatively small areas near the Harts River in the south-eastern corner of the study area.

Shorrocks, Mangano and Lichtenburg Series are well-drained soils. They are characterised by good internal drainage and weak structure. They have high, fine sand and low clay content, prominent red colours and an absence of mottling. Horizons that impede drainage are absent. Kaolinite is the principal clay mineral and the exchange capacity varies betwean two and eight milli-equivalents percent. Calcium and magnesium are the dominant exchange cations tiaroughout the profile.

\subsubsection{Soetmelk Series}

Soetmelk is the non-lithosol series covering the largest area in the quarter degree study area. It occurs throughout the area not underlain by dolomite.

Restricted drainage is a characteristic of Soetmelk soils. With increasing depth the clay content increases and the structure becomes weak medium blocky. Red and yellow mottles associated with uncemented iron concretions are distinctive features of the lower horizons. Principal clay minerals are kaolinite and illite. Montmorillonite tends to increase in the lower 
horizons. Exchange capacities vary between four and eight milli-equivalents percent. Calcium and magnesium are the dominant cations.

\subsubsection{Rensburg, Bonheim and Lindley' Series}

The Rensburg, Bonheim and Lindley series are poorly-drained soils. Poor permeability, high clay content, high exchange capacity and strong blocky or prismatic structure are the salient features of these Series.

The occurrence of these soils, either collectively or singly, is limited in extent. Rensburg series occurs in the bed of the Harts River while Bonheim series soils are restricted to slopes of the Harts River valley, where the river leaves the dolomite substrate. Lindley series occurs in small patches north and north-west of Lichtenburg. It is usually underlain by dolomite.

\subsubsection{Kalkbank Series}

The feature common to Kalkbank sandy type and Kalkbank loamy type soils is the underlying surface limestone formation encountered at shallow depths. Where the limestone is buried deeper the soil is usually Soetmelk series. The parent materials are either aeolian sand, drift materials, or both.

These soils cover areas of moderate size, usually in complexes, to the west of Lichtenburg.

\subsection{Vegetation}

The vegetation of the study area is described by Acocks (1953) in his survey of the veld types of South Africa (Fig. 3).

In the South-western Transvaal, Dry CymbopogonThemeda Veld (Veld Type 50) occurs in an arc from Lichtenburg to south-west of Delareyville and then south to Wolmaransstad. This arc, comprising the northern variation of the Veld Type, is found on sandy soils. The dominant species is Themeda triandra. Cymbopogon plurinodis is the tallest grass, but is usually not common. This Veld Type lies between altitudes of $1280 \mathrm{~m}$ and $1370 \mathrm{~m}$ on flat, sandy country with a summer rainfall of 430 to $580 \mathrm{~mm}$ per annum and with frosty winters. Species of general occurrence are given in Table 2.

Species of less general occurrence include: Cynodon dactylon, Digitaria argyrograpta, D. eriantha, Panicum coloratum and Stipagrostis uniplumis.

Sandy Cymbopogon-Themeda Veld (48) occurs in the rough square bounded by Lichtenburg, Ventersdorp, Klerksdorp and Ottosdal, to the immediate east of the arc of Dry Cymbopogon-Themeda Veld. The square comprises the northern variation of the Veld Type where the altitude ranges from $1310 \mathrm{~m}$ to

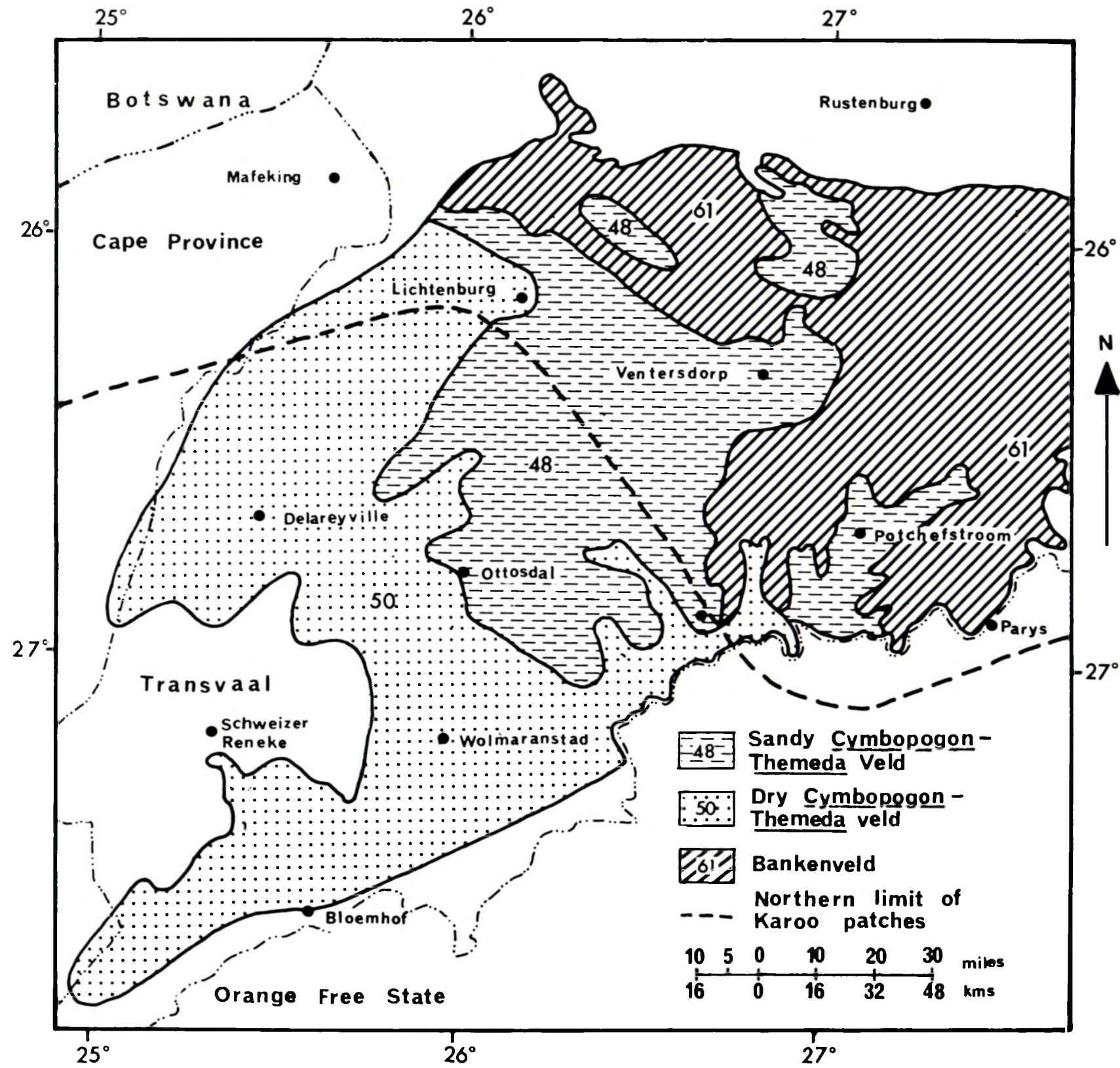

Fig. 3.-Distribution of Veld Types (Acocks, 1953) in the south-western Transvaal. 
TABLE 2.- Relative abundance values (in thousands) of those species of general occurrence, according to Acocks (1975), with relative abundances of over 1000 in Dry Cymbopogon-Themeda Veld (50), Sandy Cymbopogon-Themeda Veld (48) and Bakenveld (61)

\begin{tabular}{|c|c|c|c|c|}
\hline \multirow{2}{*}{ Species } & \multicolumn{3}{|c|}{ Veld type } & \\
\hline & 50 & 48 & 61 & \\
\hline 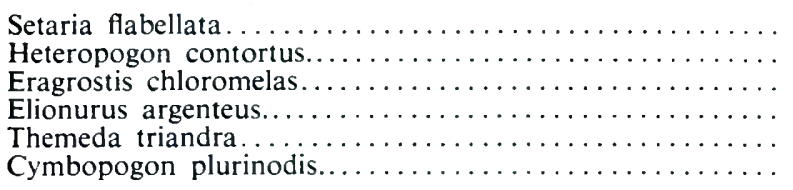 & $\begin{array}{r}142 \\
7 \\
5 \\
11 \\
165 \\
37\end{array}$ & $\begin{array}{r}121 \\
27 \\
20 \\
16 \\
39 \\
13\end{array}$ & $\begin{array}{r}109 \\
76 \\
36 \\
35 \\
30 \\
13\end{array}$ & Common to all three Veld Types \\
\hline 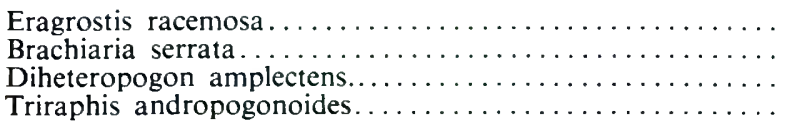 & 2 & $\begin{array}{r}20 \\
13 \\
1\end{array}$ & $\begin{array}{l}139 \\
15 \\
14 \\
2\end{array}$ & $\begin{array}{l}\text { Common to Bankenveld and one other } \\
\text { Type }\end{array}$ \\
\hline 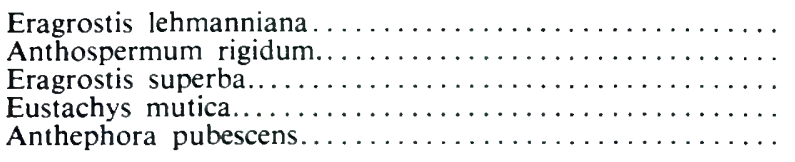 & $\begin{array}{r}26 \\
8 \\
7 \\
5 \\
5\end{array}$ & & & $\begin{array}{l}\text { Found in Dry Cymbopogon-Themeda } \\
\text { Veld }\end{array}$ \\
\hline 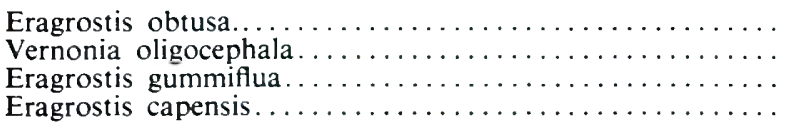 & & $\begin{array}{l}2 \\
2 \\
2 \\
1\end{array}$ & & $\begin{array}{l}\text { Found in Sandy Cymbopogon-Themeda } \\
\text { Veld }\end{array}$ \\
\hline 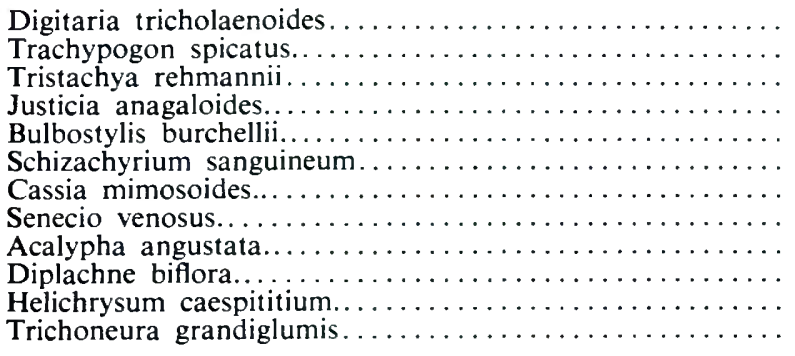 & & & $\begin{array}{r}120 \\
15 \\
5 \\
5 \\
5 \\
4 \\
3 \\
3 \\
3 \\
2 \\
2 \\
1\end{array}$ & Found in Bankenveld \\
\hline
\end{tabular}

$1520 \mathrm{~m}$ and summer rainfall is from 510 to $690 \mathrm{~mm}$. Winters are frosty. Species of general occurrence are listed in Table 2. Species of less general occurrence include Cynodon dactylon, Cynodon incompletus, Digitaria argyrograpta and Helichrysum rugulosum. According to Acocks, this Veld Type merges into the western variation of Bankenveld and needs more study. Dry $C y$ mbopogon-Themeda Veld usually occurs at a slightly lower elevation than Sandy $C y m b o p o g o n-$ Themeda Veld and usually receives slightly less rain.

Sandy Cymbopogon-Themeda Veld and Dry $C y m-$ bopogon-Themeda Veld are both Pure Grassveld Types while Bankenveld (61) is a False Grassveld type. Bankenveld occurs in a belt from east of Ventersdorp, to Klerksdorp and Parys. The Western variation occurs near Lichtenburg. It is found on sandy plains and low, rocky ridges, ranging in altitude from $1370 \mathrm{~m}$ to $1680 \mathrm{~m}$ and receives 560 to $690 \mathrm{~mm}$ rain, mostly in summer. It is a rather sparse, sour, strongly tufted vegetation and, in the nature of its grasses, is clearly transitional, according to Acocks, from Sandy Cymbopogon-Themeda Veld to Sour Bushveld (20), which occurs north of the study area. The climax was possibly an open savanna with Acacia caffra. Species of general occurrence are given in Table 2. Species of less general occurrence include Anthospermum rigidum, Digitaria eriantha, D. monodactyla, Eustachys mutica, Kohautia amatymbica and Pygmaeothamnus zeyheri.

Tentative boundaries to Veld Types drawn by Acocks (1953) for the South-western Transvaal may be re-drawn after more intensive study. Limits of Bankenveld near Potchefstroom and Ventersdorp, east of the study area, have been accurately mapped by Grunow (1959). Photographs from NASA/ ERTS-1 flights will greatly aid the further mapping of vegetation in this area at reconnaissance szales. Bankenveld is actually found as far south as Lichtenburg, as far west as a line from Lichtenburg to Mafeking and as far east as a line from Lichtenburg to Rustenburg, although this is not apparent from Acocks's map.

\subsection{Land-use}

Broad land-use categories are closely tied to geology, soils and vegetation in the study area. The parts with deep, well-drained soils overlying all geological systems except dolomite (Dry CymbopogonThemeda- and Sandy Cymbopogon-Themeda Veld Types) are extensively ploughed. Van der Bank (1968) comments that, in practice. all soils that are ploughable have already been ploughed. The principal crop is maize and limited quantities of sunflowers, grain sorghum, groundnuts and cattle fodder are grown. It is estimated by Van der Bank (1968) that the average yield of the maize crop is about 1170 $\mathrm{kg}$ /ha although some farmers reap 1550 or more $\mathrm{kg} / \mathrm{ha}$.

Cattle ranching is the chief occupation of farmers on the dolomitic lithosols (Bankenveld Veld Type) north of Lichtenburg. Occasional sink-holes in the area, which have become filled with aeolian sand, are invariably cultivated for cash crops like maize. Some irrigation, using the good supplies of water from boreholes, is undertaken.

An alarming activity is the open-cast mining of surface limestone in the area by two cement companies. Relatively large tracts of land have been acquired and 
are being systematically laid desolate as no attempt appears to have been made to stabilise and revegetate stripped areas.

\subsection{CT Grassland and Bankenveld Land Systems}

According to Dowling (1968) and Mabbutt (1968), the land of a region is conceived as a series of Land Systems, each of which contains typical land facets, which have similar features wherever they occur and which can be readily identified on aerial photographs. When relief, geology, geomorphology, soils, vegetation and land-use are considered, two Land Systems may be recognised in the study area. These two Land Systems were treated separately in the sampling and analysis of vegetation reported in this account.

One Land System, named CT Grassland, is underlain by granite, Ventersdorp lavas, Dwyka tillite and surface limestone on the aggradational phase (aeolian sand) of the African erosion surface. Soils of Shorrocks, Mangano and Lichtenburg series are generally sandy and well-drained. The natural vegetation was Dry Cymbopogon-Themeda Veld or Sandy Cymbopogon-Themeda Veld but most of it has been destroyed for the cultivation of maize, the chief land-use.

The second Land System, named Bankenveld, is underlain by dolomite, variously covered by alluvial gravels on the Karst structural phase of the African erosion surface, and has lithosolic soils. The Veld Type is Bankenveld and cattle ranching is the main land-use.

\section{PROCEDURES USED IN THIS STUDY}

\subsection{Sampling strategy}

The most important consideration in designing the vegetation sampling strategy was ensurance of compatibility with other component projects of the ecological survey of the Highveld Agricultural Region. A common sampling strategy will enhance possibilities for integration with and extrapolation between individual surveys, including some by other officers. As J. C. Scheepers of the Botanical Research Institute, Pretoria, who is responsible for surveying the eastern half of the Region, had started field sampling before the study reported here was initiated, his general strategy, as outlined below was followed.

\subsubsection{Sample placement and size}

Initially, the 2626AA quarter degree square (Fig. 1) was taken as the study area. All lands under cultivation, or showing signs of past cultivation, as well as the town of Lichtenburg and the bed of the Harts River were excluded from the area to be sampled. The remaining area was stratified into Bankenveld and CT Grassland Land Systems (see 1.7) and physiognomic-physiographic units were delimited on 1:36000-scale aerial photographs. Morris (1973) details the stratified-random sampling strategy that was used to mark 220 sample positions within the study area and gives reasons for the study area having to be enlarged to that illustrated in Fig. 1. Briefly, insufficient suitable sampling sites were found within the quarter degree square.

The sample size of $4 \times 4 \mathrm{~m}$, chosen during pilot studies for the Highveld Survey Project, was retained for uniformity. Pilot studies had shown that a sample area of $16 \mathrm{~m}^{2}$ was both the smallest adequate sample for grassland vegetation of this kind and the largest area that could be sampled in an economicallyjustifiable time (J. C. Scheepers, pers. comm.). Species present in a belt, approximately two metres wide, around the perimeter of the sample were also recorded to aid re-allocation of samples mis-classified by asso- ciation analysis owing to the chance absence of a positive dividing species. Details of quadrat location in the field are given in Morris (1973).

\subsubsection{Habitat data}

A limited amount of habitat information was gathered. Physical factors recorded for each site included geology, geomorphology, aspect, angle of slope and exposure. Soil series (Van der Bank, 1968) and depth were recorded and then for each horizon, soil $\mathrm{pH}$, soil reaction to dilute hydrochloric acid ( $\mathrm{HCl}$ ), moist soil colour (Munsell) and soil texture were noted. Biotic influence was noted by animal type and by degree on a four-point scale from absent to very intense.

\subsubsection{Vegetation data}

Total basal cover and height and basal cover of each constituent stratum were estimated for the $16 \mathrm{~m}^{2}$ sample and the presence of all permanently-recognisable plant species was recorded. Cover-abundance on the Braun-Blanquet scale (Werger, 1973) was also noted for each species.

\subsection{Association analysis}

At the time of sampling, the only objective method for classifying vegetation known to be suitable was the hierarchical technique of the SouthamptonCanberra school (Williams \& Lance, 1958; Williams \& Lambert, 1959, 1960, 1961; Lambert \& Williams, 1962). The original technique, association analysis, has been used by a number of ecologists with varying degrees of success in a number of vegetation types in South Africa, including Van der Walt (1962) in grassland, mountain scrub and karoo vegetation, Grunow (1965a, 1965b, 1967) in bushveld, Downing (1966) in vlei vegetation, Roberts (1966), Miller (1966), Miller \& Booysen (1968) and Scheepers (1969) in grassland, Taylor (1969) and Boucher (1972) in fynbos, Downing (1972) in savanna and woodland vegetation and Coetzee (1972) in Bankenveld. Although more advanced analyses had been carried out successfully (for example: Grunow \& Lance, 1969), the computer programs were not available in South Africa when the analyses reported here were carried out.

The monothetic-divisive technique of association analysis, used for classification in this account, is so well known as not to require detailed description. Briefly, quadrats to be classified are hierarchically divided on the basis of the presence or absence within each quadrat of the species with the highest association [Chi-squared $\left(\chi^{2}\right)$ in one or other form] with every other species. Division by this strategy has been found to remove most heterogeneity from the parent population of quadrats, resulting in groups with a higher degree of homogeneity than any other grouping.

An analysis was carried out on the 220 quadrats $\left(16 \mathrm{~m}^{2}\right)$ of the study area and then another was carried out on the 110-quadrat subset of Bankenveld Land System quadrats. The former, known below as the Total analysis, was done to obtain an overall classification of the vegetation of the area and, in particular, to distinguish the main vegetation types. The second analysis, known as the Bankenveld analysis, was done to obtain more detailed information about Bankenveld, the area whose natural and seminatural vegetation was of most importance. The Bankenveld analysis was necessary as the Total analysis did not separate the Bankenveld from the CT Grassland Land System clearly enough. In both analyses, the division parameter used was $\Sigma\left(\chi^{2} / N\right)^{\frac{1}{2}}$. 


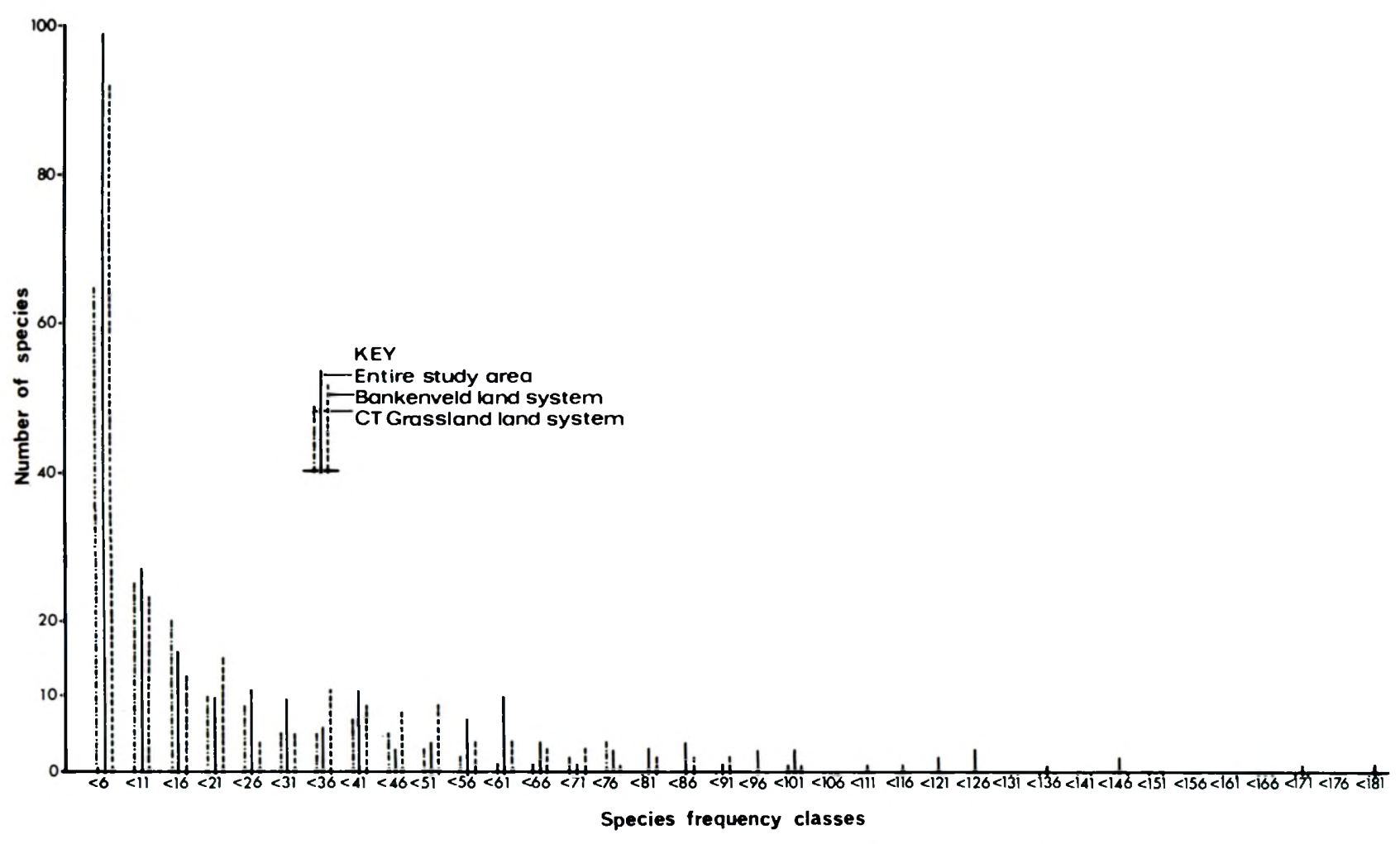

FIG. 4.-Number of species present in each species frequency class over entire study area, within Bankenveld and within CT Grassland Land Systems.

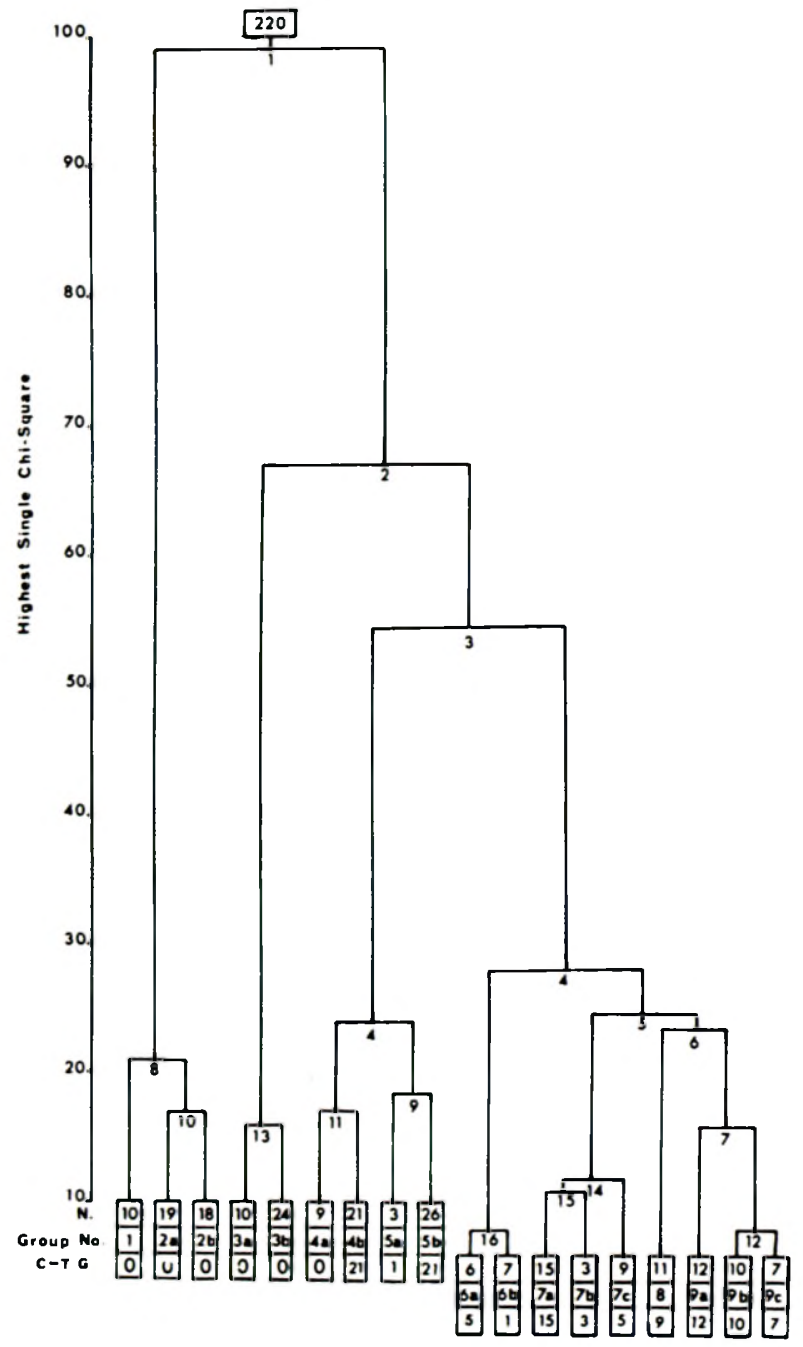

FIG. 5.-Association analysis hierarchy of Lichtenburg study area. $\mathrm{N}$. = total numter of quadrats in each group and C-TG is number of CT Grassland Land System quadrats in group. Dividing species are: $1=$ Schizachyrium sanguinzum, $2=$ Kohautia omahekensis, $3=$ Brachiaria serra! a, 4 =Stipagrostis uniplumis, $5=$ Crabbea angustifolia, $6=$ Heteropogon contortus, $7=$ Triraphis andropogonoides, $8=$ Eustachys mutica, $9=$ Bulbostylis burchellii, $10=$ Loudetia simplex, $11=$ Indigofera daleoides, $12=$ Barleria macrostegia, $13=$ Eragrostis lehmanniana, $14=$ Hermannia depressa, $15=$ Blepharis integrifolia, 16 = Vernonia oligocephala. 
Subdivision was terminated when the highest single $\chi^{2}$ (with Yates's correction) failed to exceed $3,84(\mathrm{p}=0,05)$, or less than eight quadrats remained in the group. (The neutral term 'group' is preferred to 'association', which has a specific meaning in the Braun-Blanquet sense (Werger, 1973), while other neutral terms like 'community' could have been used). For each analysis, species occurring in fewer than six quadrats were masked as it was presumed that those species were rare enough not to have Indicator value. Their exclusion greatly increased the speed of computation. In each analysis, straight lines were drawn across the hierarchies at fairly low highest single $X^{2}$ levels and groups existing at those levels were numbered from left to right. From that level, groups were interpreted downwards to the final groups of the analysis and upwards to the first division.

Although, for economy of reference in the text, groups are usually referred to by numbers and letters, it was required that defined groups be given names as well. The suffix 'Bankenveld' was used to name all groups of the Bankenveld Land System and 'Grassland', 'Woodland' and 'Savanna' suffixes were used for association analysis groups of the CT Grassland Land System. One or two species were chosen for inclusion in the name. Where possible, positive dividing species from the association analysis were used but species with significant Indicator values or high cover-abundance ratings (see later) were also used. In order to create unique names, it was sometimes necessary to overlook a species which appeared suitable as it was even more appropriate for another group.

\subsection{Presence and Indicator value}

Presence and presence percentage were calculated for every species in every group. Presence is the number of times a species occurs in the quadrats of a group and presence percentage is presence expressed as a percentage of the number of quadrats in the group.

Indicator value (Goodall, 1953) for each species was also calculated. Indicator value, according to Goodall, expresses the presence of a species in a particular group against its presence in all other groups.

\subsection{Re-allocation}

Inspection of final groups suggested that because their habitat data were markedly dissimilar from those of other quadrats of the group, certain quadrats were misclassified. By reference to species listed from the area surrounding each 4 by $4 \mathrm{~m}$ quadrat they were re-allocated to other groups on the basis of the dividing species of the hierarchy. Some quadrats, which, from inspection, appeared misclassified but which could not be satisfactorily re-allocated by the above method were left in their original groups and are discussed with those groups, as misplaced quadrats.

\section{CLASSIFICATION OF THE VEGETATION BY ASSOCIATION ANALYSIS}

\subsection{Summary statistics of data}

The total number of species encountered in the 220 quadrats was 247. Within Bankenveld, 211 species were noted, only 36 fewer than in all the quadrats, whereas only 165 species were found in CT Grassland quadrats. Proportions of common and uncommon species are summarised in Fig. 4. The shapes of all three graphs indicate that many species are uncommon (have low overall presence) and that a few species are very common (have high overall presence).
Within the entire area nearly 100 species occurred in fewer than six quadrats. Of these, 35 occurred in only one quadrat and 26 in only two quadrats. As nearly 40 percent of the species were uncommon (defined as species occurring in five or fewer quadrats), it was decided to mask uncommon species from the association analyses. Within Bankenveld, 92 species occurred in fewer than six quadrats, 42 species occurred in only one quadrat and 24 were found in only two quadrats.

The commonest species in Bankenveld were Aristida congesta, Justicia anagaloides and Themeda triandra, occurring in 97,87 and 86 of the 110 quadrats, respectively. Over the entire study area, Themeda triandra was the species occurring most frequently (in 184 quadrats). Other commonly-occurring species were Aristida congesta (171 quadrats), Elionurus argenteus (150 quadrats), Anthospermum rigidum (149 quadrats) and Justicia anagaloides (136 quadrats).

A Bankenveld quadrat contained most species (54). In CT Grassland, the highest number of species in a quadrat was 36 . In Bankenveld, the lowest number of species was 18, and in CT Grassland it was 11 . The average number of species in a Bankenveld quadrat was 36,5 [standard deviation $(\mathrm{SD})=7,5$ ] and in $\mathrm{CT}$ Grassland the average was $24,3 \quad(\mathrm{SD}=5,5)$. The overall average was $30,4(\mathrm{SD}=9,0)$.

\subsection{Total association analysis}

\subsubsection{Description of hierarchy}

The association analysis hierarchy classifying all 220 quadrats is given in Fig. 5. The quadrats are divided into four major groups. These four groups are very distinct, being maintained from a level of H.S. $\chi^{2}>54,0$ (H.S. $\chi^{2}$ is the abbreviation used for highest single chi-square throughout this account) to H.S. $\chi^{2}<28,5$ in the case of the third and fourth groups and more than double that amount in the case of the first group. At a level of H.S. $\chi^{2}=20,0$ there are nine groups and at a level of H.S. $\chi^{2}=15,0$ there are 14 groups. At the 14-group level the mean number of quadrats per group is 15,7. Inspection of the results showed that certain subgroups of the fourth major group could be profitably subdivided to a lower level than H.S. $\chi^{2}=15,0$. Thus, divisions above H.S. $\chi^{2}=7,5$ are shown for this major group in Fig 5, where different base lines are used to indicate the two levels of subdivision. As the fourth major group contains more than one third (36 percent) of the quadrats, sub-division to a lower level results in groups that are, in general, not much smaller than those in the other major groups (Table 3).

TABLE 3.-Statistics of major groups

\begin{tabular}{|c|c|c|c|c|}
\hline $\begin{array}{l}\text { Major group } \\
\text { number }\end{array}$ & $\begin{array}{l}\text { No. of } \\
\text { final } \\
\text { groups }\end{array}$ & $\begin{array}{l}\text { Mean no. } \\
\text { of } \\
\text { quadrats } \\
\text { per final } \\
\text { group }\end{array}$ & $\begin{array}{c}\mathrm{SD} \text { of } \\
\text { mean }\end{array}$ & $\begin{array}{c}\text { Percentage } \\
\text { of total } \\
\text { no. of } \\
\text { quadrats }\end{array}$ \\
\hline $\begin{array}{l}1 \ldots \ldots \ldots \\
2 \ldots \ldots \ldots \\
3 \ldots \ldots \ldots \\
4 \ldots \ldots \ldots \\
4 \ldots \ldots \ldots \ldots\end{array}$ & $\begin{array}{l}3+ \\
2+ \\
4+ \\
9 * \\
5+\end{array}$ & $\begin{array}{r}15,7 \\
17,0 \\
14,8 \\
8,9 \\
16,0\end{array}$ & $\begin{array}{r}4,9 \\
9,9 \\
10,6 \\
3,6 \\
6,6\end{array}$ & $\begin{array}{l}21,4 \\
15,5 \\
26,7 \\
36,4 \\
36,4\end{array}$ \\
\hline
\end{tabular}

+ at H.S. $\chi^{2}=15,0$

* at H.S. $\chi^{2}=7,5$

There are three final groups in the first major group, two in the second, four in the third and nine in the fourth major group. The mean number of quadrats in the final groups of each major group is given in Table 3. At H.S. $\chi^{2}=15,0$ the mean number of 
quadrats per final group is remarkably similar for the four major groups. The standard deviation of the mean for each major group, however, indicates more variation in number of quadrats per group within the second and third major groups than within the first and fourth groups. At H.S. $\chi^{2}=15,0$ the overall mean number of quadrats per final group is 15,7 with a standard deviation of 0,76 . With the finer sub-division of the fourth major group to H.S. $\chi^{2}=$ 7,5 the mean becomes $12,1(\mathrm{SD}=3,5)$.

Groups are numbered from 1 to 9 at the H.S. $\chi^{2}=$ 20,0 level and further subdivisions are labelled alphabetically and numerically. Groups are usually referred to in the text by number for brevity although, as was mentioned previously, groups are also named after dominant species and appropriate habitat features.

\subsubsection{Re-allocation}

Following the procedure described earlier, quadrat 114 , originally in Group 3a, was transferred to $4 b$, quadrat 112 from 3 b to 5 b, quadrat 152 from 9 a to $7 \mathrm{a}$ and quadrat 126 from 9c to $9 \mathrm{a}$. Except where otherwise indicated all results given above and below and including results in all tables and figures relate to groups after re-allocation.

\subsubsection{Interpretation of major groups}

The association analysis did not completely separate Bankenveld from CT Grassland Land Systems. The first two major groups are, however, largely Bankenveld and the last two mainly CT Grassland. Before re-allocation, the first major group consisted of 47 Bankenveld quadrats and no CT Grassland quadrats and the second major group of 34 Bankenveld and two CT Grassland quadrats. After re-allocation, the first two major groups consisted entirely of Bankenveld quadrats. Thus, the presence of either Schizachyrium sanguineum or Kohautia omahekensis (the first two dividing species) in a quadrat is a good indication of Bankenveld. The absence of these species does not, however, indicate CT Grassland as 29 of the 110 Bankenveld quadrats also contain neither of these species. Nine of these 29 quadrats make up Group ta, two occur in Group 5a, five in Group 5b, seven in Group 6. four in Group 7c and two in Group 8. The H.S. $\chi^{2}$ division levels indicate that quadrats of the first major group are very distinct and are not related to any quadrats outside Bankenveld. The second major group is almost as distinct. The slight admixture of Bankenveld quadrats in the third and fourth major groups suggests that some Bankenveld quadrats are floristically related to some CT Grassland quadrats but that the reverse does not hold.

\subsubsection{Final groups}

As a separate association analysis of Bankenveld quadrats was carried out, a description is not given of the first two major groups and their final groups and of Group 4a, which are made up entirely of Bankenveld quadrats. As presence percentage data are presented in a modified Roman table (Werger, 1973), where groups and species have been shuffled to highlight noda, the following discussion of groups is not strictly in the order in which groups were split off the hierarchy.

\section{(a) Group 4b (Short Stipagrostis uniplumis Cal- careous Grassland)}

Group $4 b$ is the first CT Grassland group to be split off. The quadrats form a homogeneous group with regard to species composition and habitat. with the exception of three quadrats, which are somewhat aberrant with regard to habitat. As it was not possible to re-allocate these three quadrats by reference to the species in the surrounds, they were retained in the Group.

With two exceptions, all quadrats occur on shallow aeolian sand overlying surface limestone. In a few cases the sand deposit is over $30 \mathrm{~cm}$ deep, so that the soil may be classified as Soetmelk series. but in general it is a 2,5 to $10 \mathrm{~cm}$ deep lithosol. All quadrats are situated on a flat plain with virtually no relief. Soil $\mathrm{pH}$ is usually 7,5 but occasionally 7,0 or 8,0 . Soil $\mathrm{HCl}$ reaction is usually strong or moderately strong in shallow soil and weaker where the soil is deeper. A negative correlation, significant at $p=0,01$ was found between soil depth (in $\mathrm{cm}$ ) and $\mathrm{HCl}$ reaction recorded on a $0,1,2,3$ intensity scale. Grazing was light, or absent, for most quadrats of this Group. In about one third of the quadrats selective grazing was observed and in four quadrats heavy grazing and trampling were recorded. Basal cover data are given in Table 4 together with mean number of species per quadrat. As the overall average number of species per quadrat in CT Grassland is about 24. quadrats of this Group are relatively rich in species. Species commonly occurring in quadrats of Group $4 \mathrm{~b}$ are listed in Table 4. All species with a presence greater than 39 percent are listed and species with lower presence but positive, significant Indicator values are also included. Brachiaria serrata, Stipagrostis uniplumis and Themeda triandra occur in all 21 quadrats of the Group. Possible indicator species, i.e. species which are common within the Group but are uncommon through the rest of the study area. include Fingerhuthia africana, Geigeria burkei and Convolvulus ocellatus var. ornatus, although the latter is present in only 12 of the quadrats of the Group.

\section{(b) Group 6 (Tall Stipagrostis uniplumis Calcareous} Grassland)

Group 6 is a small group of 13 quadrats, of which six were located in CT Grassland. All the quadrats are located west of Lichtenburg. some near the town and some as far as $25 \mathrm{~km}$ away. All but one of the quadrats occur on flat plains underlain by surface limestone deposits. Slope is negligible and sites are very exposed. One quadrat occurs on a flat plain where sand. over $100 \mathrm{~cm}$ deep. overlies dolomite and gravels of the Transvaal System.

Soil over the limestone is sandy and usually 30 to $50 \mathrm{~cm}$ deep. Soil $\mathrm{pH}$ is 7.0 or 7.5 and soil $\mathrm{HCl}$ reaction is slight or absent. Grazing was usually light and average total basal cover for both strata was 13.7 percent. While Stipagrostis uniplumis is the only species occurring in all six CT Grassland quadrats of Group 6 (Table 4), the Group is too small for any Indicator values to be significant. Both Stipagrostis uniplumis and Themeda triandra reach high coverabundance values in quadrats of this Group. No species with a presence of over 49 percent is restricted in distribution to quadrats of this group.

\section{(c) Similarities between Groups 4 b and 6}

Groups 4b (Short Stipagrostis uniplumis Calcareous Grassland) and 6 (Tall Stipagrostis uniplumis Calcareous Grassland) have many features in common. In addition to the similarity of dividing species (Fig. 5). these Groups share the same geological substrate. geomorphology and soils. Soils are, however, slightly deeper in Group 6 and $\mathrm{HCl}$ reaction is only slight. or absent, in contrast with the strong or moderately strong reaction in Group $4 \mathrm{~b}$. Mean basal cover of the tall grass stratum in Group 6 was double that in Group $4 \mathrm{~b}$. The mean number of species per quadrat 
TABLE 4.-Mean number of species per quadrat and mean basal cover by stratum and presence percentage of common species in each group where arrangement of species and groups follows a Braun-Blanquet Roman Table order. X indicates a high coverabundance rating for the species in most, if not all, quadrats of the group and a dash (-) indicates a value of less than $40 \%$

\begin{tabular}{|c|c|c|c|c|c|c|c|c|c|c|}
\hline Group & $4 b$ & 6 & $5 b$ & 8 & $7 b+c$ & $7 \mathrm{a}$ & $9 \mathrm{a} \mathrm{i}$ & $9 \mathrm{a}$ ii & $9 b$ & $9 c$ \\
\hline $\begin{array}{r}\text { Mean no. of species quadrat..... } \\
\text { Standard deviation of mean..... } \\
\text { Mean basal cover: total } \% \ldots \ldots \\
\text { tall stratum } \% \\
\text { short stratum } \%\end{array}$ & $\begin{array}{r}26,3 \\
4,9 \\
9,4 \\
3,8 \\
5,5\end{array}$ & $\begin{array}{r}26,3 \\
7,4 \\
13,7 \\
8,0 \\
5,7\end{array}$ & $\begin{array}{r}26,5 \\
5,2 \\
8,4 \\
2,2 \\
6,3\end{array}$ & $\begin{array}{r}23,1 \\
4,4 \\
10,4 \\
4,0 \\
6,4\end{array}$ & $\begin{array}{r}23,6 \\
3,1 \\
7,5 \\
2,0 \\
5,5\end{array}$ & $\begin{array}{r}26,4 \\
4,5 \\
9,1 \\
2,7 \\
6,4\end{array}$ & $\begin{array}{r}21,8 \\
5,2 \\
6,3 \\
1,7 \\
4,5\end{array}$ & $\begin{array}{r}22,0 \\
11,0 \\
8,3 \\
2,8 \\
5,5\end{array}$ & $\begin{array}{r}20,7 \\
2,1 \\
5,4 \\
1,0 \\
4,4\end{array}$ & $\begin{array}{r}15,2 \\
3,7 \\
6,2 \\
1,6 \\
4,6\end{array}$ \\
\hline SPECIES & & & & & & & & & & \\
\hline Geigeria burkei....... & 48 & - & $\ldots$ & - & - & - & - & - & - & - \\
\hline Euphorbia sp (M \& B 70)* . . . & 38 & - & - & - & - & - & - & - & - & - \\
\hline Selago holubii...................... & 33 & - & - & - & - & - & - & - & - & - \\
\hline Wahlenbergia caledonica.......... & 33 & - & - & - & - & - & - & - & - & - \\
\hline Salvia radula................ & 29 & - & - & - & - & - & - & - & - & - \\
\hline Scabiosa columbaria ............ & 29 & - & - & - & - & - & - & - & - & - \\
\hline Mariscus capensis............. & 24 & $-\bar{c}$ & - & - & - & - & 一 & - & - & - \\
\hline Stipagrostis uniplumis........... & $100 \mathrm{X}$ & $100 X$ & - & - & - & - & - & - & - & - \\
\hline Fingerhuthia africana $\ldots \ldots \ldots \ldots$ & 71 & 50 & - & - & - & - & - & - & - & - \\
\hline Convolvulus ocellatus var. ornatus & 57 & 50 & - & - & - & - & - & - & - & - \\
\hline Brachiaria serrata............. & 100 & - & 100 & - & - & - & - & - & - & - \\
\hline Dicoma a nomala ................... & 81 & - & 55 & - & - & - & - & - & - & - \\
\hline Aristida diffusa var. burkei...... & $76 \mathrm{X}$ & - & 60 & - & - & - & - & - & - & - \\
\hline Chascanum hederaceum......... & - & - & 40 & - & - & - & - & - & - & - \\
\hline Helichrysum zeyheri............ & - & - & 30 & - & - & - & - & - & - & - \\
\hline Heteropogon contortus........... & 48 & - & 95 & 100 & $75 \mathrm{X}$ & - & - & - & - & - \\
\hline Hibiscus microcarpus . . . . . . . . . . & - & - & 50 & 67 & - & - & - & - & - & - \\
\hline Lasiosiphon capitatus......... & - & - & 50 & 56 & - & $\overline{-1}$ & - & - & - & - \\
\hline Gazania krebsiana .............. & - & - & 45 & 44 & - & 67 & - & - & - & - \\
\hline Hermannia betonicifolia......... & - & 50 & - & 56 & - & - & - & - & - & - \\
\hline Nolletia ciliaris................ & - & 50 & - & 44 & - & - & - & - & - & - \\
\hline Pogonarthria squarrosa........... & - & - & - & 56 & - & - & - & - & - & - \\
\hline Cymbopogon excavatus.......... & - & - & - & 44 & - & - & - & - & - & - \\
\hline Raphionacme hirsuta........... & - & - & - & 44 & - & - & - & - & - & - \\
\hline Diplachne fusca $\ldots \ldots \ldots \ldots \ldots \ldots$ & - & - & - & 56 & 50 & - & - & - & - & - \\
\hline Acalpyha sp. (M \& E 1267)* ... & 48 & - & - & - & 50 & - & - & - & - & - \\
\hline Cassia mimosoides.............. & - & - & - & - & 50 & - & - & - & - & - \\
\hline Hypoxis sp. (not collected)...... & - & - & $\bar{a}$ & - & 50 & 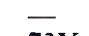 & - & - & - & - \\
\hline Aristida canescens............. & - & - & 35 & - & - & $73 \mathrm{X}$ & - & - & - & - \\
\hline Helichrysum caespititium........ & - & - & - & 44 & - & 67 & - & - & - & - \\
\hline Crabbea hirsuta .............. & - & - & - & - & 一 & 53 & - & $-\infty$ & - & - \\
\hline Eragrostis stapfii.............. & - & - & - & - & - & 47 & - & - & - & - \\
\hline Euphorbia pseudotuberosa....... & - & - & - & - & - & 47 & - & - & - & - \\
\hline Rhynchosia totta............. & - & - & - & - & - & 40 & - & - & - & - \\
\hline Euphorbia inequilatera .......... & 76 & - & - & - & - & 53 & - & 67 & - & - \\
\hline Corchorus asplenifolius........... & 76 & - & - & - & - & 47 & - & - & - & - \\
\hline Thesium costatum... & 43 & - & - & - & - & - & 56 & - & - & - \\
\hline Dicoma macrocephala............ & - & - & - & - & - & - & 44 & - & - & - \\
\hline Lippia scaberrima.............. . & - & - & - & - & - & - & 67 & - & 90 & - \\
\hline Brayulinea densa............... & - & - & - & - & - & - & - & - & 50 & - \\
\hline Lasiocorys capensis........... & - & - & - & - & - & - & - & - & 50 & - \\
\hline Antizoma angustifolia........... & - & - & - & - & - & - & - & - & 40 & - \\
\hline Panicum coloratum............ & - & - & - & - & - & - & - & - & - & 71 \\
\hline Acacia karroo........ & - & - & - & - & - & - & - & - & - & 43 \\
\hline Aptosimum indivisum.......... & - & - & - & - & - & $\overline{0}$ & $\overline{-10}$ & $\overline{0}$ & $\overline{-10}$ & 43 \\
\hline Blepharis integrifolia............ & - & - & - & - & - & 100 & 78 & 100 & 70 & 71 \\
\hline Eragrostis lehmanniana.......... & - & - & - & - & - & 60 & $78 \mathrm{X}$ & $67 \mathrm{X}$ & 50 & 57 \\
\hline Hermannia depressa.............. & - & - & - & 44 & - & 100 & 56 & 67 & 40 & \\
\hline Hibiscus pusillus............. & - & - & - & - & - & 60 & - & 67 & 40 & 57 \\
\hline Felicia muricata $\ldots \ldots \ldots \ldots \ldots$ & — & - & - & - & - & 53 & - & - & 90 & 43 \\
\hline Sporobolus africanus............. & - & - & - & - & - & - & 67 & - & $90 x$ & 71 \\
\hline Solanum supinum..... & - & - & - & - & - & - & 78 & 67 & 70 & - \\
\hline Setaria flabellata... & - & - & 85 & 89 & $63 \mathrm{X}$ & 80 & 56 & 67 & 40 & 71 \\
\hline Eragrostis curvula.. & - & - & 65 & 89 & 75 & 87 & $67 \mathrm{X}$ & $100 \mathrm{X}$ & $70 \mathrm{X}$ & $71 x$ \\
\hline Cymbopogon plurinodis......... & - & - & 50 & - & 75 & $80 \mathrm{X}$ & 44 & $100 x$ & 40 & - \\
\hline Digitaria argyrograpta........... & - & - & 45 & 67 & - & 47 & 89 & - & 40 & $86 \mathrm{X}$ \\
\hline Justicia anagaloides.. & - & - & 85 & 44 & 63 & 40 & 44 & - & - & - \\
\hline Eragrostis gummiflua... & - & - & 40 & 56 & - & - & $78 \mathrm{X}$ & - & - & $\overline{-a}$ \\
\hline Eustachys mutica.............. & - & - & - & 67 & 50 & 80 & $89 \mathrm{X}$ & $100 \mathrm{X}$ & - & 57 \\
\hline Cynodon dactylon... & - & - & - & - & 50 & - & $44 \mathrm{X}$ & & $90 \mathrm{X}$ & 71 \\
\hline Themeda triandra.... & $100 \mathrm{X}$ & $83 \mathrm{X}$ & 95 & 78 & $100 \mathrm{X}$ & 100 & 89 & 100 & 60 & $71 X$ \\
\hline Aristida congesta.. & - & 83 & 70 & 89 & 75 & 67 & 100 & 67 & 80 & 43 \\
\hline Elionurus argenteus.. & $81 X$ & 67 & $90 \mathrm{X}$ & $67 \mathrm{X}$ & $50 \mathrm{X}$ & $87 \mathrm{X}$ & - & $100 X$ & 40 & - \\
\hline Barleria macrostegia....... & 67 & 67 & 65 & 67 & 50 & 93 & - & 100 & 100 & - \\
\hline Anthospermum rigidum. & 43 & 67 & 85 & 89 & 88 & 73 & 44 & - & 40 & - \\
\hline Triraphis andropogonoides........ & 62 & - & 65 & 67 & 88 & 60 & $89 \mathrm{X}$ & $100 \mathrm{X}$ & - & - \\
\hline Eragrostis superba.. & - & 67 & - & - & - & 73 & 78 & - & 80 & - \\
\hline Crabbea angustifolia..... & 76 & - & 70 & - & 100 & 93 & - & - & - & - \\
\hline Vernonia oligocephala........... & - & 83 & 50 & - & 63 & - & - & - & - & - \\
\hline Total number of species..... & 24 & 24 & 12 & 28 & 19 & 24 & 21 & 15 & 22 & 15 \\
\hline
\end{tabular}

- Specimens of Morris \& Boucher 70 and Morris \& Engelbrecht 1267, housed in National Herbarium, Pretoria. 
was the same in both Groups. Three species, Stipagrostis uniplumis, Fingerhuthia africana and Convolvulus ocellatus var. ornatus were common in these two Groups but nowhere else.

Most of the area formerly occupied by Short and Tall S. uniplumis Calcareous Grassland has been ploughed for maize cultivation. Most of the rest, where the soil is too shallow for ploughing. has been excavated to supply limestone for local cement factories or has, at least, been bought for this use in future. The area covered by Tall and Short $S$. uniplumis Calcareous Grassland is decreasing rapidly as a result of this activity.

(d) Group 5b (Elionurus argenteus Secondary Grassland)

As Group 5b is the last group of the third major group of the hierarchy, a certain amount of heterogeneity in floristics as well as in habitat was expected. Heterogeneity will be apparent from the description which follows.
Quadrats of this Group occur in three main clusters north-west, north-east and south of Lichtenburg, respectively. Various geological substrates underlie quadrats of this Group. Half are underlain by Ventersdorp lava, quartzites, brecchia or conglomerate, four are on deep sand overlying dolomite and chert of the Transvaal system and two quadrats each are found on surface limestone, Archaean granite and Dwyka tillite. Three quadrats face north on very gentle slopes and the others occur on flat plains or crests of hills. Half the quadrats in this Group have soil over $80 \mathrm{~cm}$ deep and the rest are on shallower soil with an average depth of $15 \mathrm{~cm}$. All quadrats are found on Soetmelk soil series. Soil pH is usually 6,5 but values of 6,0 or 7,0 are occasionally recorded. Biotic influence varied widely. Some quadrats were only lightly grazed while others were heavily grazed and some showed signs of soil erosion. All heavily-grazed quadrats were located on deep soil while only light grazing was recorded on shallow soils. Mean total basal cover was slightly lower than in Group 4b and mean number of species per quadrat was almost the

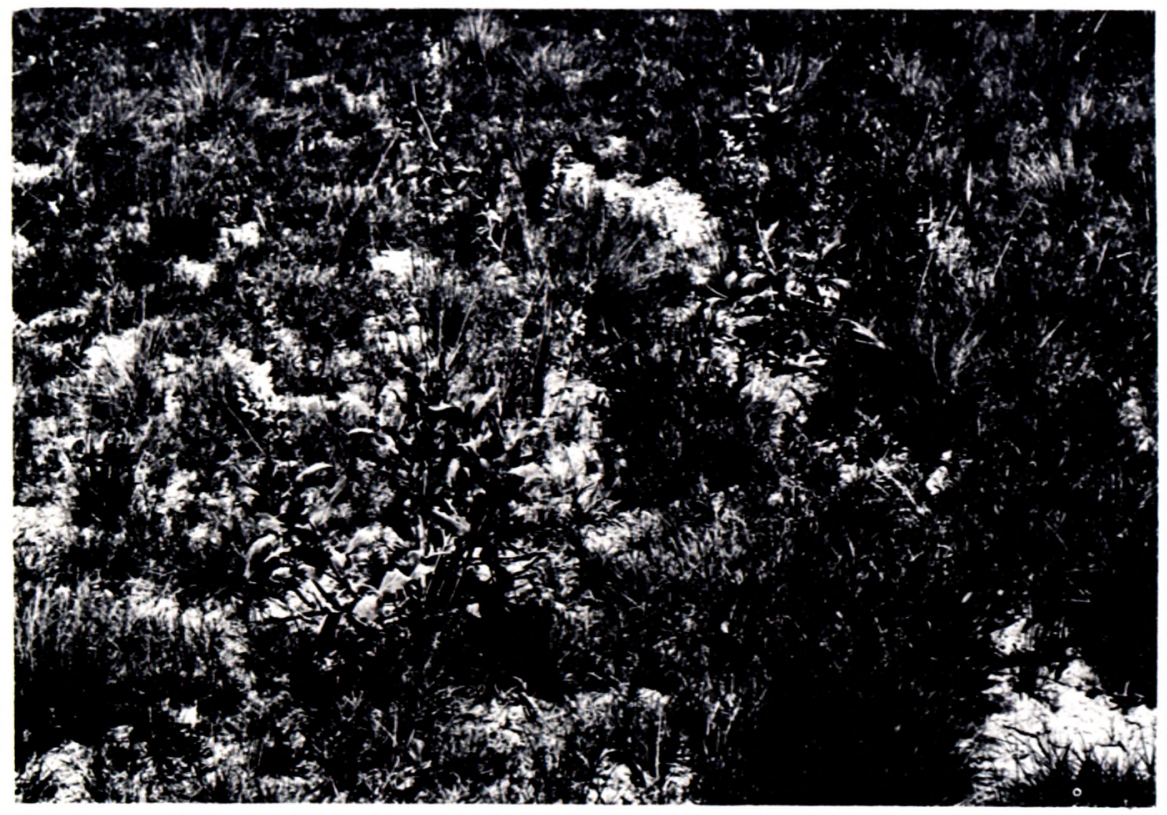

FIG. 6.-Salvia radula, $50 \mathrm{~cm}$ tall, in Short Stipagrostis uniplumis Calcareous Grassland. Grasses include $S$. uniplumis, Brachiaria serrata, Themeda triandra, Aristida diffusa var. burkei and Elionurus argenteus. Hendriksrust, Lichtenburg District.

FIG. 7.-Desolation of an abandoned, flooded open-cast calcrete mine. Plant colonisation of such areas is slow. This site was previously Stipagrostis uniplumis Calcareous Grassland. East of Lichtenburg on Town Lands.

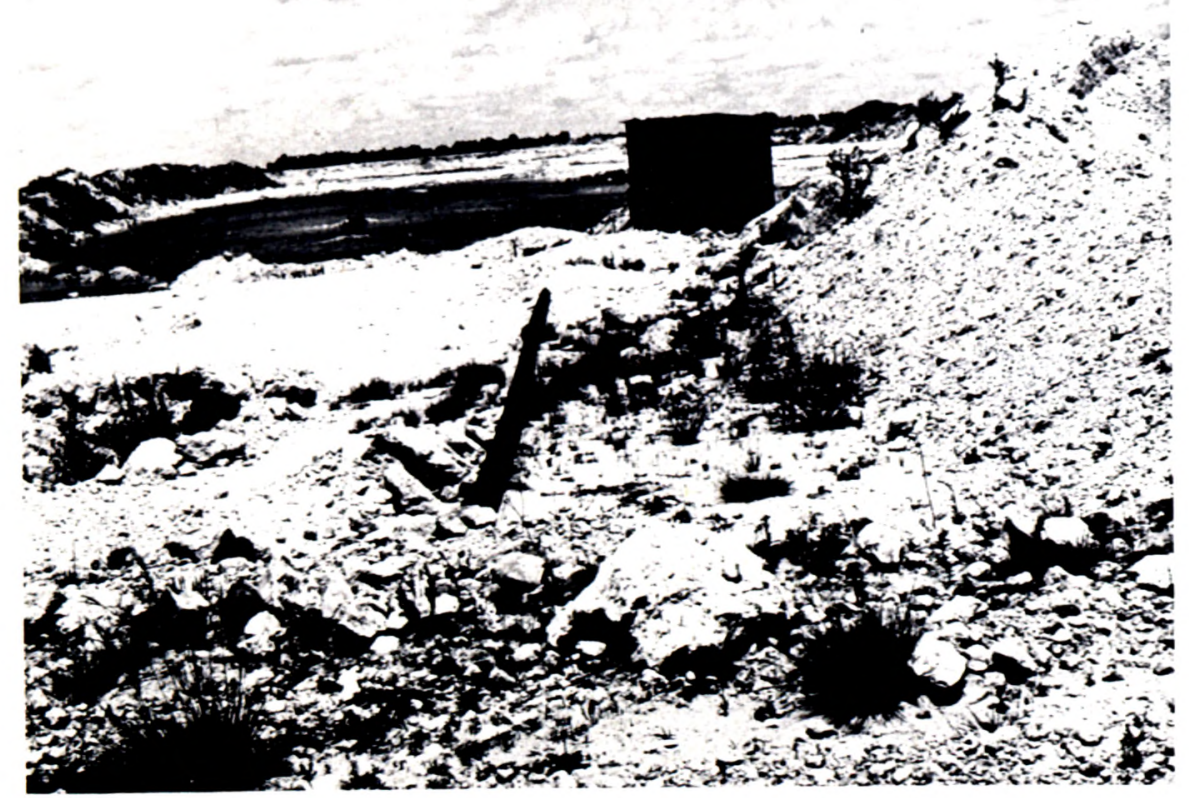


same in both groups (Table 4). Species commonly occurring in quadrats of Group 5 b are listed in Table 4. Only Brachiaria serrata occurs in all quadrats. Elionurus argenteus, after which the Group is named, is the only species with high cover-abundance in many quadrats of the Group. No species with high presence percentage have significant Indicator values. Only Chascanum hederaceum and Helichrysum zeyheri are not recorded in the floristic summary of any other group.

(e) Group 8 (Elionurus argenteus Primary Grassland)

Quadrats of Group 8 occur mainly at two places, east of and west of Lichtenburg, respectively.

Five quadrats occur on Ventersdorp conglomerate, lava or quartzites, three on sand overlying dolomite and gravels and one on Dwyka tillite. Quadrats are on extensive flat plains or on gentle waxing slopes. The soils developed from the three rock types all belong to Soetmelk series. Soils are usually $60 \mathrm{~cm}$ to over one metre deep, soil $\mathrm{pH}$ is usually between 6,5 and 7,0 and no soil $\mathrm{HCl}$ reaction is recorded. With only one exception, the quadrats of this Group were not grazed or were only lightly grazed and in good condition. Species present in more than 39 percent of the quadrats of Group 8 are listed in Table 4.

Heteropogon contortus is the only species occurring in all 9 quadrats of this Group. The Group is too small for any indicator values to be significant. High cover-abundance values were only rarely recorded for species in quadrats of this Group. In addition to the widespread grass, Elionurus argenteus, Eragrostis gummiflua and Eustachys mutica were the only species with high cover-abandance values in three or more quadrats.

\section{(f) Similarities between Groups $5 \mathrm{~b}$ and 8}

Groups 5b (Elionurus argenteus Secondary Grassland) and 8 (Elionurus argenteus Primary Grassland) have a number of features in common and the reason for the association analysis split is not clear. Most quadrats of both Groups are found on rocks of the Ventersdorp System, on flat plains and where the soil series is Soetmelk. In Group $5 b$, half the quadrats are on shallow soil (mean depth $15 \mathrm{~cm}$ ), while the other half are on deeper soil (over $80 \mathrm{~cm}$ ) while in Group 8, soils are usually over $60 \mathrm{~cm}$ deep. Soil pH and $\mathrm{HCl}$ reaction are similar in the two Groups. In Group 5b, quadrats on the deeper soils were heavily grazed while quadrats on the shallower soils were rested or only lightly grazed. In Group 8, where the soil is generally deep, grazing is light or the vegetation has been rested. One of the main differences is, thus, a disturbance factor of grazing pressure interacting with the occurrence of shallow soil, resulting in the names 'primary' and 'secondary' for these Elionurus argenteus Grasslands. Basal cover of the tall grass stratum is slightly higher in Group 8 than in Group $5 \mathrm{~b}$ but cover of the short grass stratum is the same. A slightly greater number of species occur in quadrats of Group 5b than in those of Group 8. Hibiscus microcarpus and Lasiosiphon capitatus were the only species which occurred commonly in these two Groups and nowhere else. Nine species (Table 4) occurred in over 60 percent of the quadrats of both Groups $5 \mathrm{~b}$ and 8 . Species which are common in Group 5b (in over 60 percent of the quadrats) but are either rare in, or do not occur in Group 8 (less than 60 percent of the quadrats) include Brachiaria serrata (the dividing species between the two groups), Aristida diffusa var. burkei, Crabbea angustifolia and Justicia anagaloides. Eustachys mutica is the only species found in over 60 percent of the quadrats of Group 8 and in fewer than 40 percent of the quadrats of Group $5 \mathrm{~b}$.

\section{(g) Group 7}

Fifteen quadrats of Group 7, defined by the presence of both $H$. depressa and $B$. integrifolia, form a distinct Group, 7a, made up entirely of CT Grassland quadrats (Fig. 5). The Group defined by the absence of $B$. integrifolia, $7 \mathrm{~b}$, contains only three quadrats and as it appears related to Group 7c, it is discussed with it.

Quadrats of Groups $7 \mathrm{~b}$ and $7 \mathrm{c}$ occur scattered through the study area. Floristic parameters are summarised in Table 4 . The quadrats are found on a number of geological substrates and soil series. Taree quadrats are located on surface limestone (Soetmelk soil series), three on sand overlying dolomite and gravels (Soetmelk series), one on granite and one on Ventersdorp brecchia and conglomerate. All are on exposed, flat sites. In most quadrats, grazing was light or the vegetation had been rested for some time before sampling. Heavy grazing was recorded from two quadrats. Species occurring in more than three of the eight CT Grassland quadrats of these Groups are listed in Table 4. Only two species, Crabbea angustifolia and Themeda triandra occur in all eight quadrats. Themeda triand a, Heteropogon contortus and Setaria flabellata had high cover-abundance

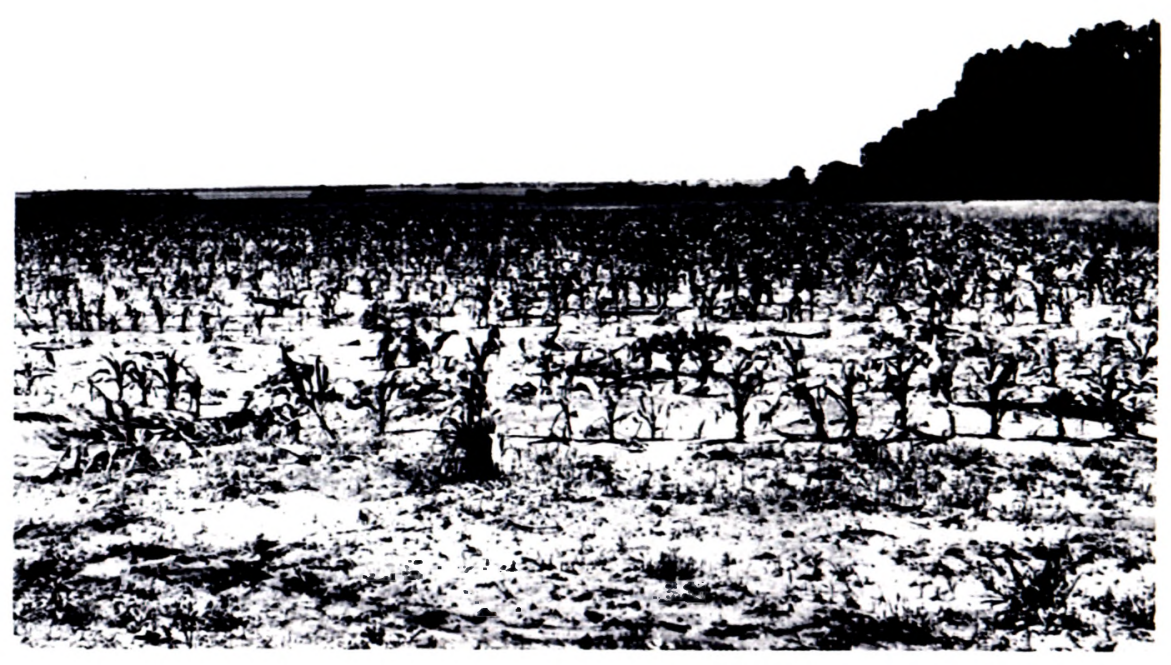

Fig. 8.-Extensive maize cultivation in CT Grassland Land System. This area was Elionurus argenteus Grassland before cultivation. Exotic Eucalypus sp. shown on right, shallow valley of Harts River in middle distance and town of Lichtenburg on horizon. Rietgat, Lichtenburg District. 
estimates in most quadrats of the Groups. The combined Group is too small for any Indicator values to be significant.

Groups $7 \mathrm{~b}$ and $7 \mathrm{c}$ do not form distinct units. As a number of quadrats apparently belonging to other Groups appear to be included in these Groups, evidenced by the lack of uniformity in habitats, and as they are small groups, they are not named.

Only one quadrat (120) appears mis-classified in Group $7 \mathrm{a}$ (Cymbopogon plurinodis Grassland). As it could not be re-allocated by reference to the species in the surround, it was left in the Group. Quadrat 152 was re-allocated to this Group from 9a. Quadrats of Group 7a occur in two clusters near each other. One cluster borders Lichtenburg to the south-east and the other is east of the town. With the exception of quadrat 120 , quadrats of this Group are located on flat plains underlain by Dwyka tillite. Slope is one percent or less and sites are exposed. The soil series in all quadrats is Soetmelk. Average soil depth is about one metre and soil $\mathrm{pH}$ is 7.5 or 8.0 . A slight soil $\mathrm{HCl}$ reaction is occasionally recorded. On the other hand, quadrat 120 occurs in a slight hollow on a flat plain covered with surface limestone. The soil series is Kalkbank. Soil depth is about $40 \mathrm{~cm}$ with a pH of 7,5 and no soil $\mathrm{HCl}$ reaction. Within Group 7a, biotic influence was most variable. Some quadrats enjoyed total protection from grazing, as within the Lichtenburg aerodrome reserve, while others in the municipal commonage were heavily grazed and trampled. All species with a presence exceeding 39 percent in quadrats of Group 7a are listed in Table 4. Blepharis integrifolia, Hermannia depressa and Themeda triandra occur in all 15 quadrats. High coverabundance values were recorded for Elionurus argenteus, Cymbopogon plurinodis and Aristida canescens. Eragrostis stapfii, Rhvnchosia totta, Euphorbia pseudotuberosa and Crabbea hirsuta are not common enough to be included in the floristic summary of any other Group.

\section{(h) Group 9}

Twelve quadrats are split off Group 9 at H.S. $\chi^{2}$ $=16,0$ to form Group 9a, within which two slightly different subgroups $(9 \mathrm{a}$ i and $9 \mathrm{a}$ ii) are recognised. Group $9 \mathrm{c}$ is the last group of this analysis and is defined by the absence of all dividing species. Quadrat 126 was re-allocated from Group 9c to the first subgroup of $9 \mathrm{a}$ and quadrat 152 was re-allocated from the first subgroup of $9 \mathrm{a}$ to Group 7a on the bases of species recorded in the surrounds of these quadrats. Subgroups of Group 9 have a number of features in common. Most of the quadrats are on Ventersdorp system rocks. The soil is usually deep with a $\mathrm{pH}$ of 6,0 or 7,0 . In nearly all quadrats, grazing was heavy and trampling was recorded. Grass basal cover was low and the mean number of species per quadrat was about 20, the lowest of any group of the analysis.

Quadrats of Group 9a (Acacia karroo Savanna) (9a i) and Secondary $C y m b o p o g o n$ plurinodis Grassland (9a ii) occur scattered through the area east of Lichtenburg. Four quadrats occur together with a cluster of Group 9c quadrats. One quadrat (126), which was re-allocated to this Group. occurs west of Lichtenburg and differs from the rest of the Group in other respects as well.

Quadrats of the first subgroup of Group 9a (9a i), named Acacia karroo Savanna, occur on Ventersdorp quartzites while those of the second subgroup (9a ii), named Secondary Cymbopogon plurinodis Grassland, are found on Dwyka tillite substrate. Quadrat 126, the aberrant, re-allocated quadrat, occurs on a surface limestone deposit. Quadrats of the first subgroup occur on extensive flat plains or on waning slopes to streams while those of the second subgroup occur on flat plains or waxing slopes. In all cases, slopes are very slight (one degree or less). About half the quadrats are moderately-exposed and half are exposed.

A number of soil series are represented in the first subgroup. including Lichtenburg. Soetmelk and Rensburg, while all three quadrats of the second subgroup are on Soetmelk series. Soils are relatively deep. averaging about $90 \mathrm{~cm}$. Soil $\mathrm{pH}$ varies between 6.0 and 7,0 and no soil $\mathrm{HCl}$ reaction is recorded. In all the quadrats of this Group, grazing was heavy and the vegetation had been trampled. Trees were invading grassland at a number of Group 9a i sites. The most common tree was Acacia karroo which occurred as a seedling or full-grown tree up to $4 \mathrm{~m}$ tall. Ziziphus mucronata occurred occasionally as well as the following shrubs: Asparagus laricinus, Diospyros lycioides and Maytemus heterophylla.

Basal cover was low in quadrats of Group 9a i. Average total basal cover was only 6.3 percent. Mean number of species per quadrat in both subgroups was about 22,0. Spacies present in more than 39 percent of the quadrats of Group $9 \mathrm{a}$ i are listed in Table 4. Aristida congesta is the only species occurring in all quadrats of the Group. Eustachys mutica, Triraphis andropogonoides, Eragrostis gummiflua, E. lehanniana and E. curvula have high cover-abundance estimates in most quadrats of the Group. Species present in more than one of the three quadrats of Group $9 \mathrm{a}$ ii are listed in Table 4. As there are only three quadrats in the Group, these presence values should not be relied on. Both Groups $9 \mathrm{a}$ i and $9 \mathrm{a}$ ii are too small for any Indicator values to be significant. Species which are more common in Group $9 \mathrm{a}$ i than Group 9a ii include: Digiraria arglrograpta, Eragrostis gummiflua, E. superba, Lippia scaberrima, Thesium costatum and Sporobolus africanus. As Group 9a ii is so small, species presence in it are not known accurately. The following species, however, appzar more common in Group 9a ii than in 9a i: Crmbopogon plurinodis, Elionurus argenteus, Euphorbia inequilatera, Barleria macrostegia and Hibiscus pusillus.

There are many similarities between Group $7 \mathrm{a}$ (C1'mbopogon plurinodis Grassland) and Group 9a ii (Secondary $C_{1}$ mbopogon plurinodis Grassland). Group $9 \mathrm{a}$ ii is, however, too small for a detailed ecological analysis and interpretation. The two Groups have geological, geomorphological and soil characteristics in common. Soils are slightly shallower in Group 9a ii than in Group 7a. Biotic influences were variable in Group 7a but grazing was heavy and trampling marked in Group 9a ii. Mean basal cover and number of species per quadrat were lower in the latter Group. As grazing and trampling are generally more severe in Group 9a ii than in 7a. the former Group is called Secondary Crmbopogon plurinodis Grassland and the latter, Cymbopogon plurinodis Grassland.

Quadrats of Acacia karroo Open Woodland (Group 9b) are distributed in two clusters, south and south-east of Lichtenburg, respectively. Nine of the ten quadrats of this Group are situated on Ventersdorp System rocks. Ventersdorp lava, conglomerate, brecchia and quartzites are represented. The remaining quadrat is located on granite. Most of the quadrats are located on flat plains or the crests of hills where slope is too slight to measure. Most of the quadrats are sheltered or moderately sheltered, in marked contrast to the quadrats of other groups described above. Sheltering is usually by the presence of trees in, or near, the quadrats. Soetmelk series, Soetmelk lithosol and Lichtenburg series are the most common soils recorded 
for these quadrats. Soil is usually $60 \mathrm{~cm}$ to one metre deep with a $\mathrm{pH}$ of 6,0 to 6,5 . Nearly all the quadrats showed signs of heavy grazing and trampling. The condition of the vegetation of even those quadrats in which grazing appeared moderate was recorded as being poor, probably as a result of heavy grazing in the past.

Basal cover in quadrats of Group $9 \mathrm{~b}$ was low. Total average basal cover was only 5,4 percent. The number of species per quadrat was low, the average being 20,7 and 24 being the highest number of species recorded in a quadrat of the Group. Species present in more than 39 percent of the quadrats of Group $9 b$ are listed in Table 4. Barleria macrostegia is the only species occurring in all ten quadrats. Brayulinea densa and Lasiocorys capensis have significant Indicator values. High cover-abundance was recorded for Cynodon dactylon, Sporobolus africanus and Eragrostis curvula within the Group. Trees and shrubs are recorded from the surrounds of six quadrats. The most common tree is Acacia karroo, which attains a height of 4,5 to $6 \mathrm{~m}$. Occasional, or co-dominant with A. karroo is $A$. caffra. Other trees found occasionally include Celtis africana $(7,5 \mathrm{~m})$, Ziziphus mucronata $(5,5 \mathrm{~m})$, Acacia robusta (rare) and Rhus lancea. In Acacia karroo Open Woodland the trees are usually one to three crown-diameters apart. Shrubs include Maytenus heterophylla, which can encroach on shallow soil with mismanagement, Xeromphis rudis, Grewia flava (occasional, or common, in understorey), Asparagus laricinus and Diospyros lycioides.

Six quadrats of Drainage Basin Acacia karroo Open Woodland (Group 9c) are located east of Lichtenburg along a tributary of the Harts River. The other quadrat (183) occurs south-east of Lichtenburg with quadrats of Groups $9 \mathrm{a}$ and $9 \mathrm{~b}$. Although the bed of the Harts River was not sampled, the whole drainage basin is probably covered by this Woodland. The geological formation underlying all the quadrats is Ventersdorp series quartzites. Two quadrats are on flat plains, four on waning slopes to drainage lines and one is in a drainage basin. Most quadrats are north-facing on gentle slopes. Four of the quadrats are sheltered by having trees in and near them.
A number of soil series are represented in Group 9c. Three quadrats are on Rensburg series alluvial clay, two on the transition between Rensburg and Soetmelk series and two on Lichtenburg series. Soils are usually one metre deep and $\mathrm{pH}$ varies between 6,0 and 7,0 . Soil $\mathrm{HCl}$ reaction is recorded from two quadrats. Heavy grazing and trampling were recorded for five of the quadrats but in two quadrats the vegetation was in good condition and grazing had been light. Total basal cover was low $(6,2$ percent), but slightly higher than in Group $9 \mathrm{~b}$. The mean number of species per quadrat was by far the lowest value for this analysis. Species present in more than 39 percent of the quadrats of Group 9c are listed in Table 4. Digitaria argyrograpta, in six of the seven quadrats, is the most common species. D. argyrograpta, Eragrostis curvula and Themeda triandra have high coverabundance estimates in quadrats of the Group. Three species, Panicum coloratum, Acacia karroo and Aptosimum indivisum are not listed as present in any other group of the analysis (Table 4). Trees and shrubs, similar to those of Group $9 b$, were recorded from four quadrats.

Individually, Groups $9 \mathrm{~b}$ and $9 \mathrm{c}$ are too small to produce many significant Indicator values. Considering that they are the last Groups of the analysis, however, asurprising number of significant Indicator values are found in the combined Group. Seven species (Felicia muricata, Digitaria argyrograpta, Lippia scaberrima, Solanum supinum, Hibiscus pusillus, Panicum coloratum and Brayulinea densa) out of the 18 species occurring in more than five of the 17 quadrats of the combined Group have significant Indicator values. Cynodon dactylon, Sporobolus africanus and Eragrostis curvula have high cover-abundance estimates in quadrats of the combined Group.

\subsection{Bankenveld association analysis}

\subsubsection{Description of hierarchy}

The association analysis hierarchy resulting from classification of the 110 Bankenveld Land System quadrats is given in Fig. 11. The first three divisions yield four distinct major groups, labeled A to D for

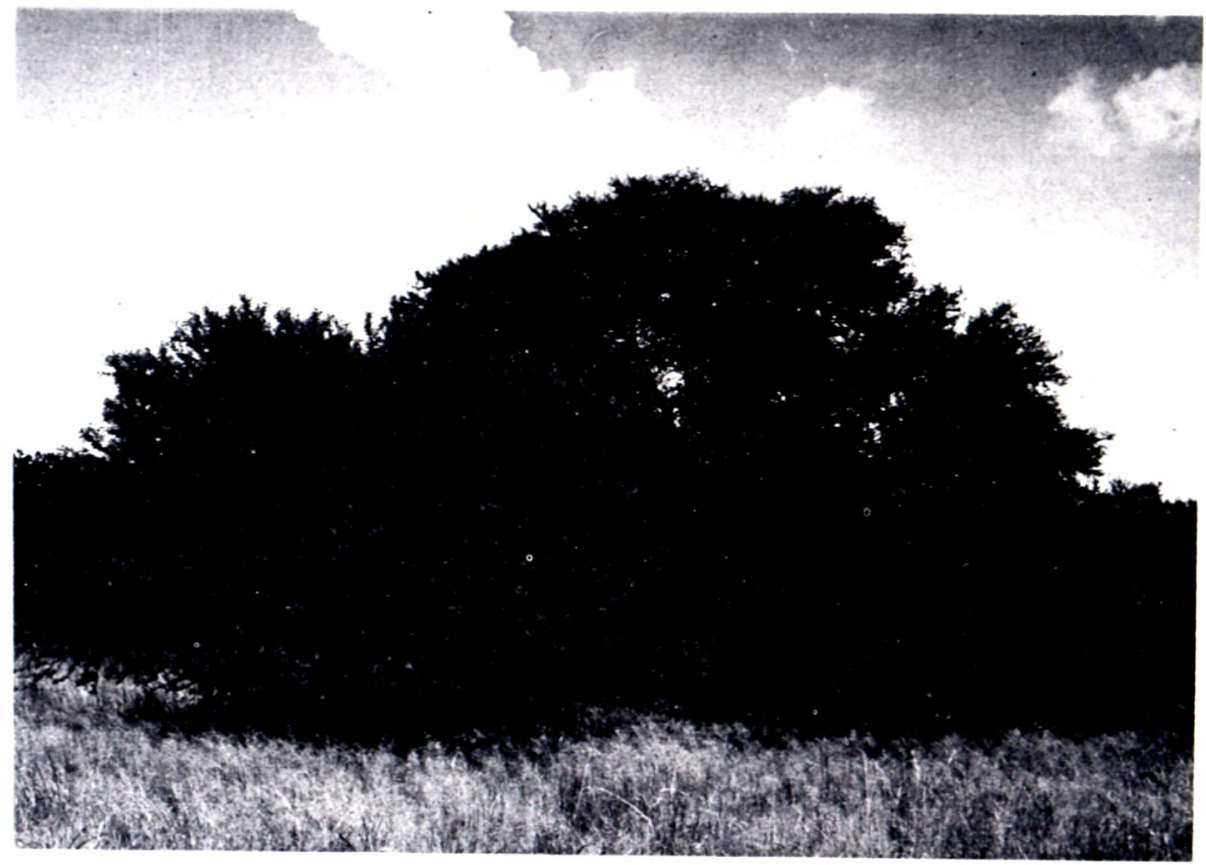

Fig. 9.-Four metre tall Acacia karroo trees in Acacia karroo Open Woodland. Rietgat, Lichtenburg District. 
FIG. 10.-Harts River in flood, January 1976. Trees on banks are mostly exotic Salix and Eucalypus species. Floodplain grassland of Drainage Basin Acacia karroo Open Woodland in foreground. Rietgat, Lichtenburg District.

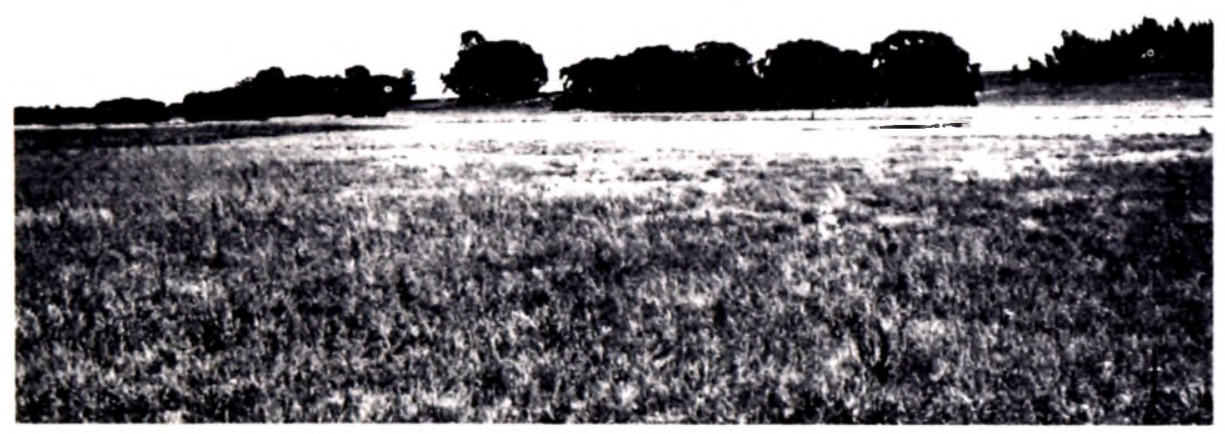

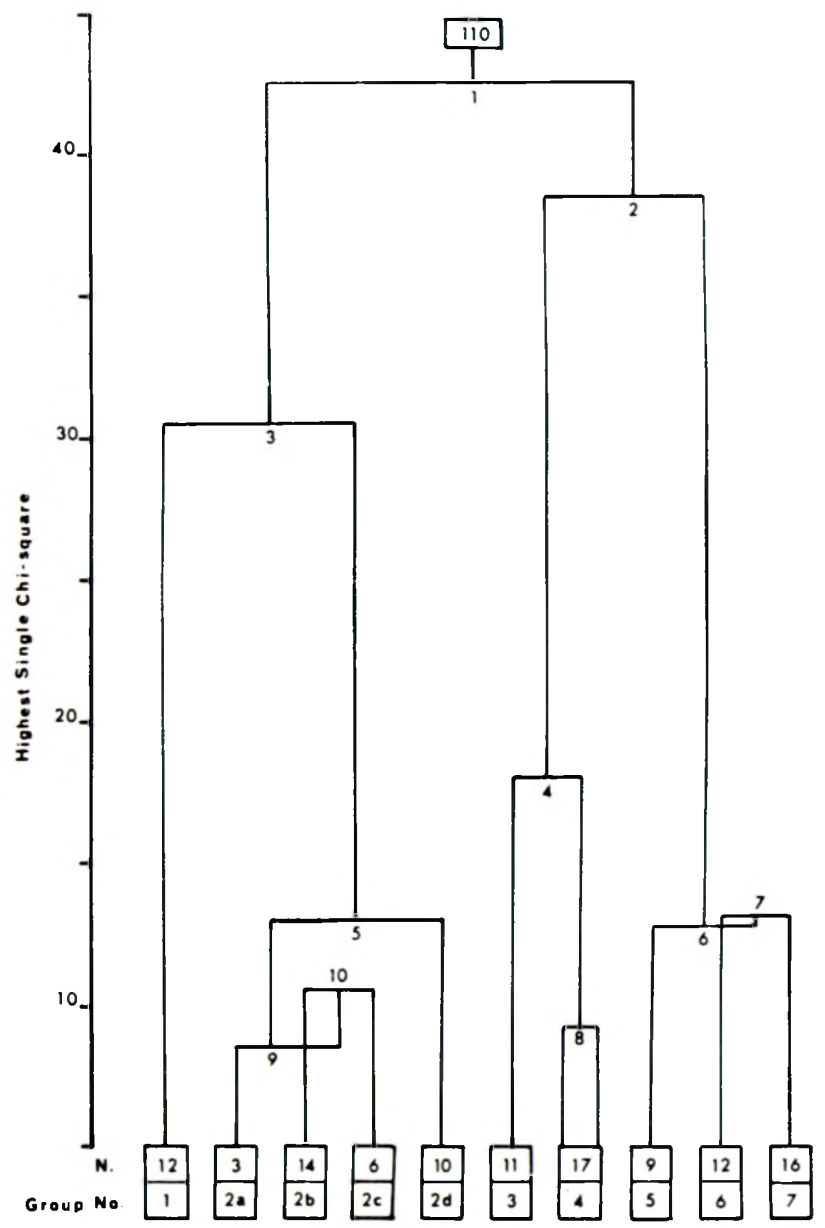

FIG. 11.-Association analysis hierarchy of Bankenveld Land System. Dividing species are: $1=$ Diheteropogon amplectens, $2=$ Chascanum hederaceum, $3=$ Stipagrostis uniplumis, $4=$ Eragrostis racemosa, $5=$ Sporobolus pectinatus, $6=$ Ursinia nana, $7=$ Oropetium capense, $8=$ Schizachyrium sanguineum, $9=$ Corchorus asplenifolius, $10=$ Heteropogon contortus.

convenience. The first Group, A, is small, consisting of only 12 quadrats. It is very homogeneous with regard to species associations as it does not divide from H.S. $\chi^{2}>30,0$ until H.S. $\chi^{2}=7,2$. In addition to being a major group it is also Final Group 1. Group B contains 33 quadrats. At H.S. $\chi^{2}=8,0$ it is divided into four Final Groups, named $2 \mathrm{a}, 2 \mathrm{~b}$, $2 \mathrm{c}$ and $2 \mathrm{~d}$. Group $\mathrm{C}$ contains 28 quadrats and is divided into two Final Groups at H.S. $\chi^{2}=15,0$. Three Final Groups are obtained from major Group D, which contains 37 quadrats. Final Groups in A and $B$ were obtained by terminating division at H.S. $\chi^{2}=8,0$ and final groups $C$ and $D$ by terminating division at H.S. $\chi^{2}=10,0$. These levels were chosen arbitrarily, for naming purposes, and divisions below these levels are discussed at appropriate places in the text.

Based on hierarchy division levels (H.S. $\chi^{2}$ ), Groups $\mathrm{A}$ and $\mathrm{B}$, on the one hand, are most dissimilar from Groups C and D on the other. Groups C and D differ more from each other than does Group A from $B$, as the former divide further at a higher H.S. $\chi^{2}$ than the latter. The small number of splits above H.S. $\chi^{2}=15,0$, at which level there are only five groups, suggests that the sample consists of a few, large groups, which are rather homogeneous. The homogeneity of $\mathbf{A}$ has already been mentioned. Major Groups C and D are also homogeneous, the former being maintained from H.S. $\chi^{2}>35,0$ to H.S. $\chi^{2}=18,0$ and the latter from H.S. $\chi^{2}>35,0$ to H.S. $\chi^{2}=12,7$.

The mean number of quadrats in each final group is fairly constant. Fewest quadrats are found in Final Groups 2a, 2b, 2c and 2d (8,2 average). On average, twelve quadrats are found in each final group of major Groups $A$ and D. The average number of quadrats in Final Groups 3 and 4 is 14,0.

Re-allocation was not required in this analysis and the few quadrats which do not fit the description of a particular group as a whole are discussed in the group description.

Group 7 is the last group of the hierarchy and is defined by the absence of all dividing species. Quadrats of this group do not form a meaningful unit, being scattered diffusely across the northern and southern boundaries of the area. This group is neither named nor discussed further as it is considered a collection of quadrats which should have been included in other groups but which, by chance, lacked the necessary defining species. Re-allocation of these quadrats was not considered worthwhile.

\subsubsection{Species distribution within groups}

When lists of species commonly occurring in each final group were drawn up as part of the interpretation of each group. it was found that large numbers of species seemed common to many groups and that there were few species that were restricted to only one or two groups. To study these findings at greater depth, a species-in-groups Table was drawn up. Five Final Groups, namely 1.3, 4, 5 and 6 and Group B (consisting of Final Groups 2a, 2b, 2c and 2d) were used for the six columns of the Table. The presence percentage of every species in each group 
was computed and rows of the Table were then formed by the 84 species, each of which had a presence of over 39 percent in at least one group. These presence percentages are given in Tables 5 and 6 where species with wide and restricted distributions, respectively, are listed. Mean number of species per quadrat and mean basal cover percent are also given in Table 5 .

The mean number of species per quadrat decreased steadily from almost 50 in Group 1 to 36,5 in Group 6 . At the same time the standard deviation of the mean increased, indicating that as the mean decreases, the range within a group increases (Table 5). Total basal cover and the cover of the tall and short grass strata are highest in Group 1 and are fairly similar in all the other groups.

All species with a presence greater than 19,9 percent in all groups, and in all groups but one, are listed in Table 5. In particular, Aristida congesta and Themeda triandra are common throughout the area if a presence of 75 percent is taken as a criterion for within-group abundance. The presence percentages of most of the other species vary from one group to another. Twenty four species have a presence greater than 19,9 percent in all groups and 22 have a presence of less than 20 percent in only one group.

The 38 species with a presence greater than 19,9 percent in four or fewer groups are listed in Table 6. It is noteworthy that only three species, Eragrostis gummiflua, Euphorbia sp. and Fingerhuthia africana, are restricted to only one group, and all three are found in Group 6 quadrats. Eight species have a presence exceeding 19,9 percent in only two groups. Many species, including Diheteropogon amplectens, Barleria pretoriensis and Eragrostis racemosa, have a similar pattern of distribution, being found with a high presence percentage in Groups 1 and $B$. Another group of species, including Oropetium capense, Sporobolus africanus and Hermannia tomentosa, are found in Groups 4, 5 and 6 although they are not all restricted entirely to these groups.

TABLE: 5.- Mean number of species per quadrat, mean basal cover percentage and presence percentage for widely distributed species wirhin each group. $X$ indicates a high cover-abundance rating for the species in most, if not all, quadrats of the groups and a dash (-) a value of less than $20 \%$

\begin{tabular}{|c|c|c|c|c|c|c|}
\hline Group & 11 & B & 3 & 4 & 5 & 6 \\
\hline 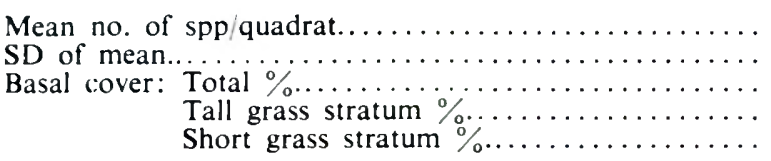 & $\begin{array}{r}49,5 \\
3,4 \\
14,0 \\
6,3 \\
7,6\end{array}$ & $\begin{array}{r}43,6 \\
5,8 \\
10,7 \\
5,0 \\
5,7\end{array}$ & $\begin{array}{r}46,6 \\
8,2 \\
9,0 \\
3,0 \\
6,0\end{array}$ & $\begin{array}{r}41,0 \\
7,1 \\
9,0 \\
3,0 \\
6,0\end{array}$ & $\begin{array}{r}40,0 \\
7,1 \\
10,6 \\
2,8 \\
7,8\end{array}$ & $\begin{array}{r}36,5 \\
7,4 \\
9,9 \\
4,9 \\
5,0\end{array}$ \\
\hline 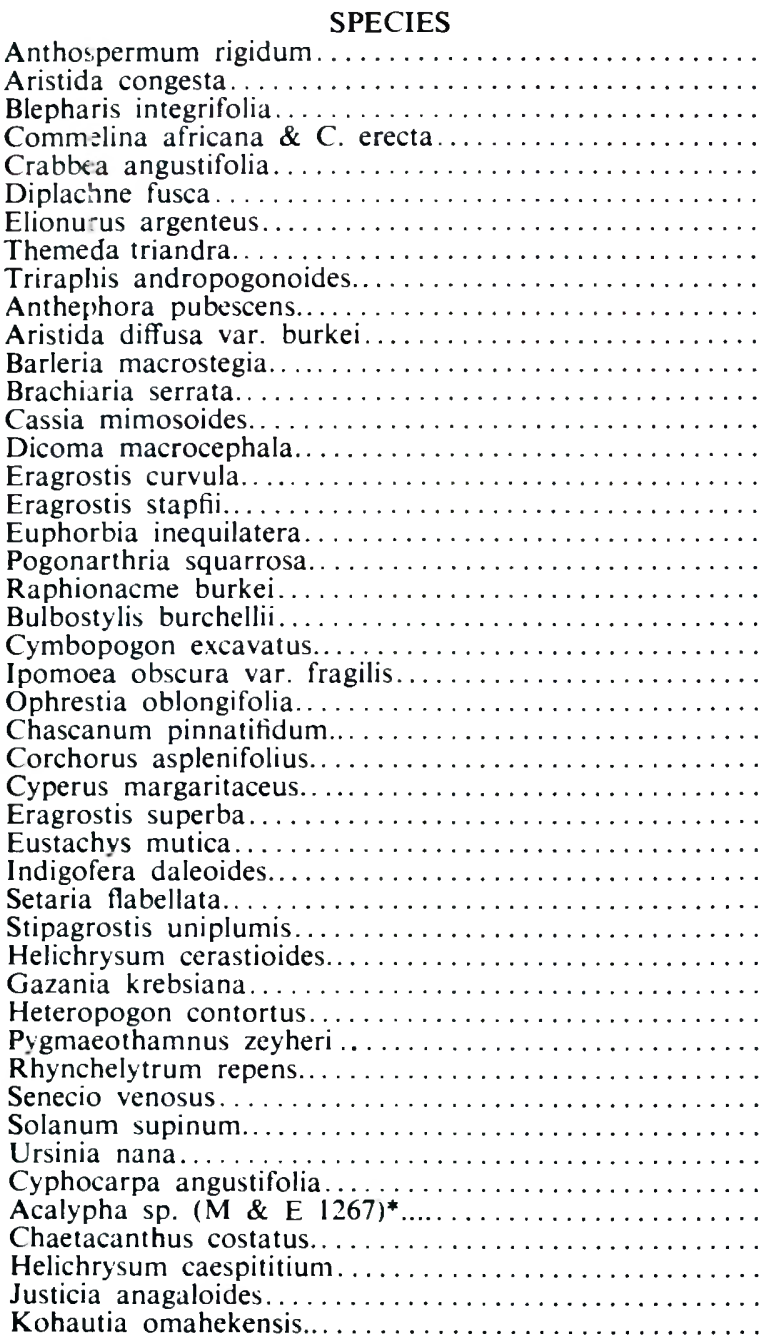 & $\begin{array}{c}100 \\
73 \mathrm{X} \\
46 \\
55 \\
100 \\
64 \\
91 \mathrm{X} \\
91 \mathrm{X} \\
91 \mathrm{X} \\
82 \mathrm{X} \\
91 \mathrm{X} \\
82 \\
100 \\
64 \\
73 \\
55 \\
64 \\
100 \\
82 \\
36 \\
55 \\
46 \\
55 \\
55 \\
46 \\
73 \\
27 \\
27 \\
46 \\
55 \\
55 \\
100 X \\
46 \\
64 \\
64 X \\
46 \\
27 \\
82 \\
27 \\
55 \\
46 \\
64 \\
64 \\
46 \\
91 \\
91\end{array}$ & 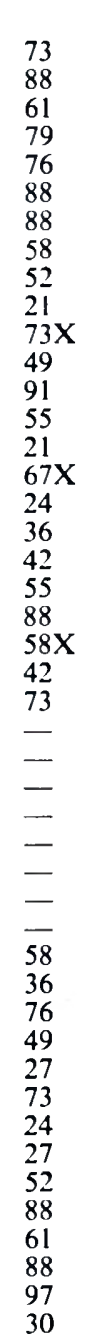 & $\begin{array}{c}73 \\
91 X \\
73 \\
82 \\
82 \\
82 \\
91 X \\
100 X \\
91 \\
55 \\
55 \\
55 \\
91 \\
64 \\
55 \\
46 X \\
36 \\
64 \\
64 \\
64 \\
64 \\
73 \mathrm{X} \\
46 \\
46 \\
27 \\
73 \\
46 \\
36 \\
36 \\
46 \\
55 \\
27 \\
64 \\
73 \mathrm{X} \\
46 \\
55 \\
46 \\
55 \\
55 \\
55 \\
55 \\
36 \\
64 \\
100 \\
73\end{array}$ & $\begin{array}{c}88 \\
100 X \\
82 \\
71 \\
82 \\
65 \\
65 X \\
100 X \\
94 \\
82 X \\
35 \\
59 \\
71 \\
53 \\
71 \\
24 \\
71 \\
82 \\
88 \\
47 \\
24 \\
35 \\
41 \\
35 \\
65 \\
53 \\
35 \\
41 \\
65 \\
65 \\
29 \\
71 X \\
53 \\
41 \\
65 X \\
24 \\
24 \\
35 \\
77 \\
71 \\
29 \\
24 \\
41 \\
41 \\
88 \\
88\end{array}$ & $\begin{array}{c}89 \\
89 \\
67 \\
78 \\
56 \\
67 \\
44 \\
78 X \\
44 \\
67 X \\
22 \\
56 \\
44 \\
22 \\
56 \\
44 \\
56 \\
78 \\
44 \\
67 \\
33 \\
33 \\
22 \\
22 \\
67 \\
100 \\
22 \\
78 \\
56 \\
78 \\
33 \\
78 X \\
56 \\
- \\
22 \\
33 \\
22 \\
.14 \\
100 \\
33 \\
44 \\
33 \\
67 \\
78 \\
89\end{array}$ & $\begin{array}{c}42 \\
100 \mathrm{X} \\
42 \\
92 \\
42 \\
42 \\
50 \\
75 \mathrm{X} \\
67 \\
67 \mathrm{X} \\
42 \\
33 \\
33 \\
42 \\
42 \\
50 \mathrm{X} \\
33 \\
83 \\
33 \\
25 \\
25 \\
33 \\
58 \\
33 \\
50 \\
50 \\
58 \\
75 \mathrm{X} \\
58 \\
58 \\
33 \\
100 \mathrm{X} \\
50 \\
42 \\
75 \\
- \\
- \\
- \\
- \\
- \\
- \\
- \\
- \\
-\end{array}$ \\
\hline
\end{tabular}

* Specimen housed in National Herbarium, Pretoria. 
TABLE 6.-Presence pzrcentage for spacies with restricted distributions within each group. X indicates a high cover-abundance rating for the species in most, if not all, quadrats of the group and a dash $(-$ ) a value of less than $20 \%$

\begin{tabular}{|c|c|c|c|c|c|c|}
\hline Group & 1 & B & 3 & 4 & 5 & 6 \\
\hline SPECIES & & & & & & \\
\hline 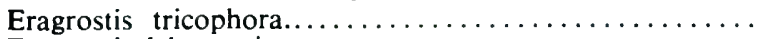 & - & - & $55 X$ & $53 \mathrm{X}$ & 44 & 33 \\
\hline 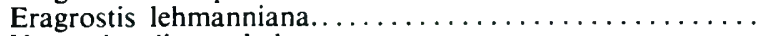 & - & 一 & 36 & 29 & $67 X$ & 67 \\
\hline 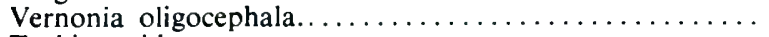 & 36 & - & - & 41 & 33 & 67 \\
\hline 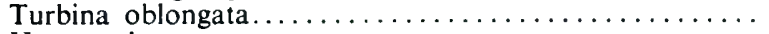 & 55 & - & - & 29 & 44 & 92 \\
\hline 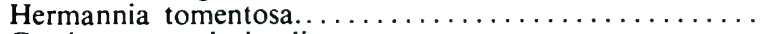 & 73 & - & 一 & 53 & 78 & 67 \\
\hline 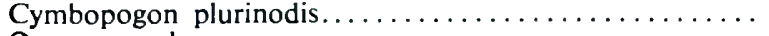 & 64 & - & - & 41 & 33 & 67 \\
\hline 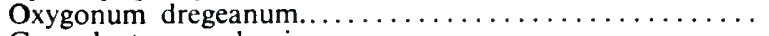 & 46 & 64 & 46 & - & 22 & - \\
\hline Crassula transvaalensis $\ldots \ldots \ldots \ldots \ldots \ldots \ldots \ldots$ & 73 & 49 & - & 29 & 44 & - \\
\hline 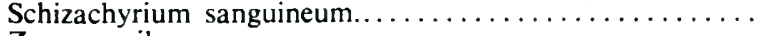 & $73 \mathrm{X}$ & $88 \mathrm{X}$ & 73 & 24 & - & - \\
\hline Zornea milneana $\ldots \ldots \ldots \ldots \ldots \ldots \ldots \ldots \ldots \ldots$ & - & 30 & 55 & 29 & 68 & - \\
\hline 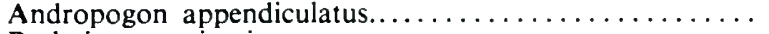 & 27 & $49 X$ & 一 & - & - & - \\
\hline 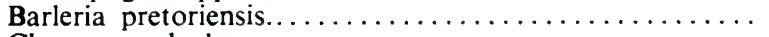 & 73 & 76 & - & - & 22 & 25 \\
\hline 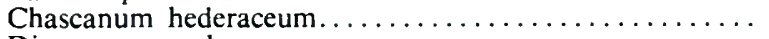 & 73 & 79 & 100 & $100 x$ & - & - \\
\hline 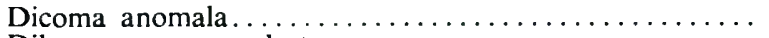 & 91 & 91 & 73 & 29 & - & - \\
\hline 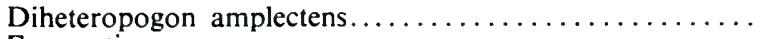 & $100 \mathrm{X}$ & $100 \mathrm{X}$ & 36 & - & 一 & - \\
\hline 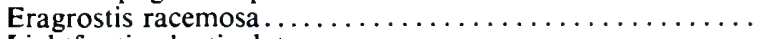 & 64 & 91 & 100 & - & - & - \\
\hline 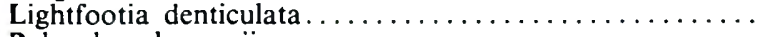 & 36 & 55 & - & - & - & - \\
\hline$\ldots \ldots \ldots \ldots \ldots \ldots \ldots \ldots$ & 46 & 21 & 27 & - & - & 一 \\
\hline 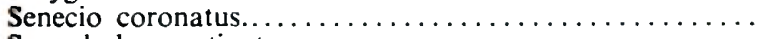 & 27 & 61 & 36 & 一 & 一 & - \\
\hline 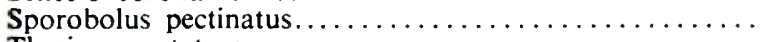 & 46 & 73 & 46 & - & - & - \\
\hline 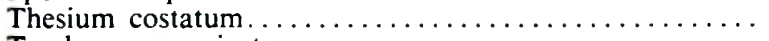 & 55 & 61 & - & 24 & - & 25 \\
\hline Trachypogon spicatus $\ldots \ldots \ldots \ldots \ldots \ldots \ldots \ldots$ & $55 \mathrm{X}$ & $73 \mathrm{X}$ & $64 X$ & - & - & 一 \\
\hline 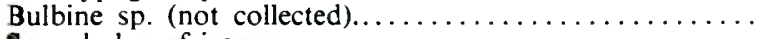 & - & - & - & 35 & 22 & 42 \\
\hline 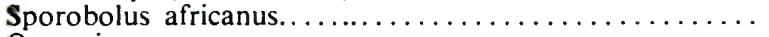 & - & $\cdots$ & - & 24 & 33 & 67 \\
\hline 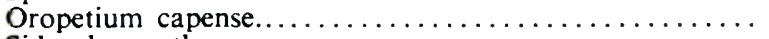 & 27 & - & - & 24 & 33 & 100 \\
\hline 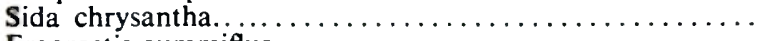 & - & - & 46 & 24 & 33 & 33 \\
\hline Eragrostis gummiflua . . . . . . . . . . . . . . & - & - & - & - & - & 42 \\
\hline Euphorbia sp. $(\mathrm{M} \& \mathrm{~B} 70)^{*} \ldots \ldots \ldots \ldots \ldots \ldots \ldots \ldots \ldots \ldots$ & - & - & - & - & - & 42 \\
\hline 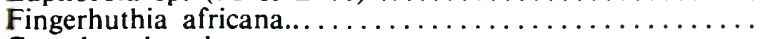 & 一 & - & - & - & - & 58 \\
\hline 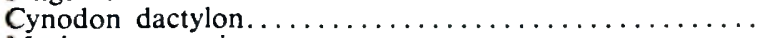 & - & - & - & - & 44 & 25 \\
\hline 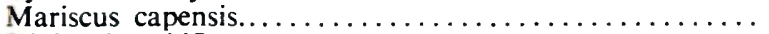 & 一 & - & 27 & - & 一 & 42 \\
\hline$\ldots \ldots \ldots \ldots \ldots \ldots \ldots \ldots$ & - & 52 & 27 & 一 & - & - \\
\hline$\ldots \ldots \ldots \ldots \ldots \ldots \ldots \ldots \ldots$ & - & 52 & 46 & - & - & - \\
\hline 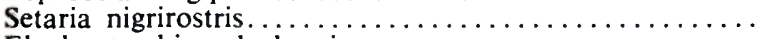 & 一 & - & - & 41 & 22 & - \\
\hline 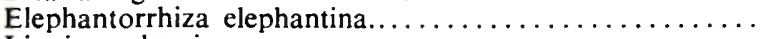 & - & 49 & 36 & - & - & - \\
\hline Lippia scaberrima.......... & $\bar{a}$ & - & 46 & - & 22 & 25 \\
\hline Menodora africana... & 27 & - & - & 41 & 22 & $\overline{-}$ \\
\hline Nolletia ciliaris..... & 27 & - & - & 24 & - & 42 \\
\hline
\end{tabular}

* Specimen housed in National Herbarium, Pretoria.

\subsubsection{Final Groups}

\section{(a) Group 1 (Diheteropogon-Stipagrostis Primary Bankenveld)}

Two small patches of quadrats of Group 1 (Diheteropogon-Stipagrostis Primary Bankenveld) are found north and north-east of Lichtenburg. Other quadrats of this Group occur scattered singly through the north-central and north-western parts of the study area. This small group represents Bankenveld on relatively deep, dolomite-derived soils that have been rested in the recent past or have at least been protected from mismanagement.

Nearly all quadrats are located on the crests of small rises, typical of the area, or on waxing slopes from rises. Two quadrats occur in small hollows. Slope is usually so slight as to be unmeasurable. Chert fragments and loose dolomite rocks are usually found on the ground surface in these quadrats. Soil depth varies from 5 to $10 \mathrm{~cm}$. Soil $\mathrm{pH}$ is usually 6,5 and occasionally 7,0. Biotic factors were uniform within the Group. Grazing intensity was light, or moderate, and often the vegetation appeared to have been rested for some time before sampling. Average total basal cover was 14 percent (Table 5), 6, 3 percent being contributed by the tall grass stratum (60 to $90 \mathrm{~cm}$ tall with many $75 \mathrm{~cm}$ tall tufts) and 7,6 percent by the short grass stratum (about $16 \mathrm{~cm}$ tall but ranging from 5 to $35 \mathrm{~cm}$ tall). Quadrats of this group are rich in species, containing the highest average number of species of any Bankenveld group studied. Species present in over 19,9 percent of the quadrats of Group 1 are given in Tables 5 and 6. (b) Group 2 (Diheteropogon-Schizachyrium Banken veld)

As a whole, Group 2 (Diheteropogon-Schizachyrium Bankenveld) appears homogeneous, being retained as an entity from H.S. $\chi^{2}=30,0$ to 13,1 . At a level of H.S. $\chi^{2}=8,5$, however, the 33 quadrats of this Group are divided into four groups. Group 2 will be described as a whole and peculiarities of each Final Group will be mentioned. Quadrats of this Group form a belt from east to west across the study area. Group $2 b$ is concentrated in the eastern and central parts of the belt. Group 2a is restricted to three quadrats in the south-western corner and quadrats of Group 2c occur among those of Group 2b. Quadrats of Group $2 \mathrm{~d}$ are found at the western end of the belt and along the south-central edge of the belt. In comparison with some other groups, whose quadrats are scattered through the study area, this is an easily delimited Group.

Over two thirds of the quadrats of Group 2 occur on crests of rises or on very gentle waxing south- and north-facing slopes. The other third, which are found scattered through all four Final Groups, are in very shallow depressions, on waning slopes to drainage lines, or in small sand-filled sink-holes. Soil is usually 5 to $8 \mathrm{~cm}$ deep with chert gravel littered on the soil surface. A solid sheet of dolomite is not found in any quadrat. Soil $\mathrm{pH}$ varies between 6,5 and 7,0 and no soil $\mathrm{HCl}$ reaction is recorded. With five exceptions all quadrats were lightly grazed or rested and the vegetation was in good condition. Some of the samples were from inside fenced maize lands on soil too shallow for 
ploughing. Vegetation in these situations was usually protected from grazing. The exceptional quadrats were heavily grazed and trampled and dolomite was often exposed in them. These quadrats are not excluded from the Group because some, if not all of them, could have been heavily grazed for too few years for their species composition to have altered from this treatment. Average total basal cover in Group 2 was 5,0 percent for the tall grass stratum (usually $75 \mathrm{~cm}$ but ranging from 60 to $90 \mathrm{~cm}$ in height) and 5,7 percent for the short grass stratum (usually in the range 15 to $30 \mathrm{~cm}$ tall). The averages for Group $2 \mathrm{~b}$ were slightly greater than the overall averages and those for groups $2 \mathrm{a}, 2 \mathrm{c}$ and $2 \mathrm{~d}$ were equal to, or slightly less than, the averages for Group 2 as a whole.
Species present in over 19,9 percent of the quadrats of Group 2 are given in Tables 5 and 6.

On the grounds of the species common to the subgroups and the similar habitat and management features of the quadrats of Group 2 it was decided not to subdivide the Group for description even though it is the largest Group of the analysis. DiheteropogonSchizachyrium Bankenveld is also the most widespread Group in the analysis. It is considered to be the "normal' or 'typical' Bankenveld of the study area. In distribution, Diheteropogon-Stipagrostis Primary Bankenveld (Group 1) forms an extension of this Group and represents a higher successional stage (less disturbance) in the Bankenveld Land System.

Fig. 12.-Featureless Bankenveld Land System scene north of Lichtenburg in Diheteropogon-Schizachyrium Bankenveld showing selective grazing. Short grass is mostly Themeda triandra and larger tufts are of Diheteropogon amplectens and Stipagrostis uniplumis. Trees are mostly Acacia karroo. Houthaalbomen, Lichtenburg District.
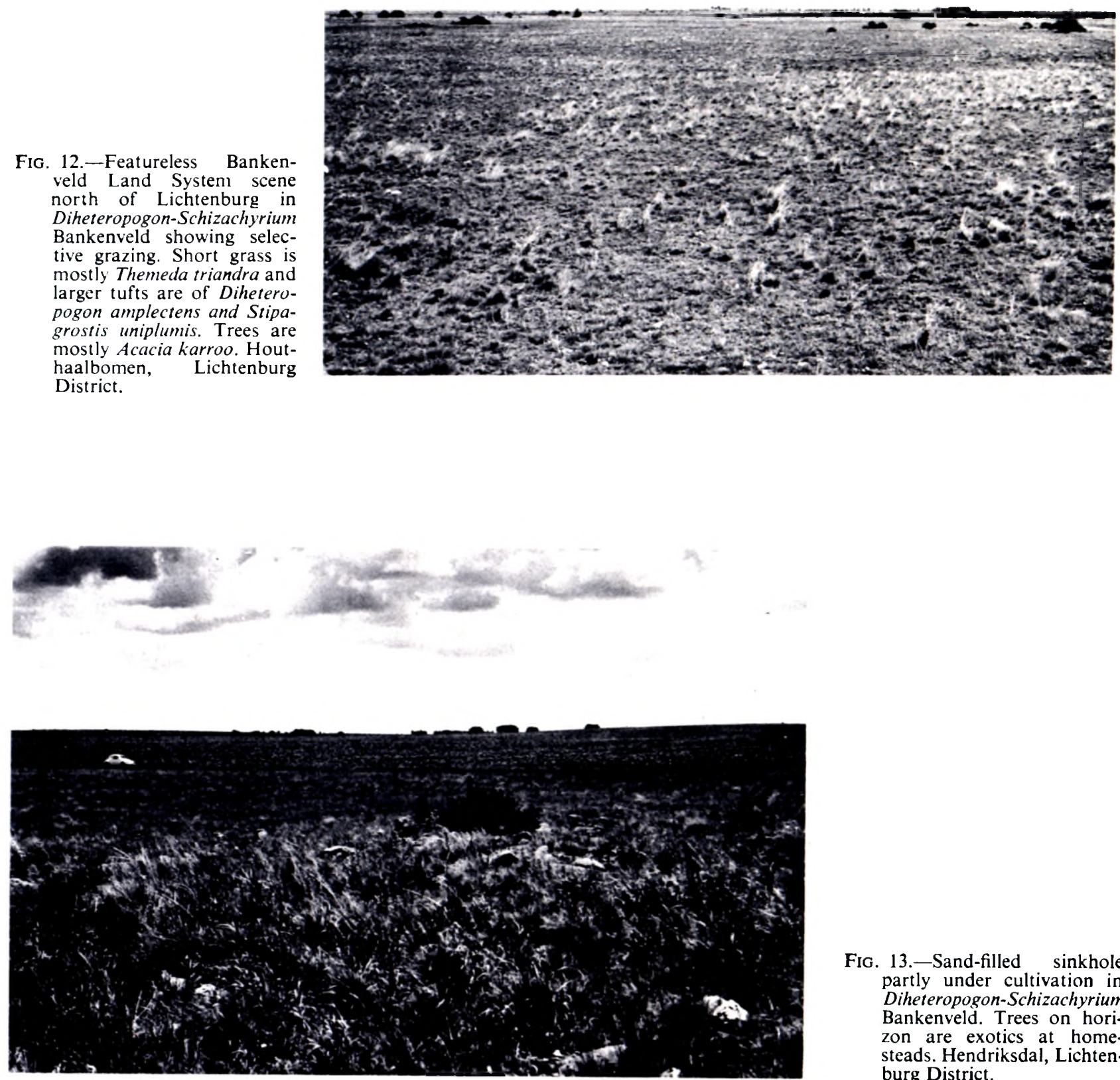

Fig. 13.-Sand-filled sinkhole partly under cultivation in Diheteropogon-Schizachyrium Bankenveld. Trees on horizon are exotics at homesteads. Hendriksdal, Lichtenburg District. 
(c) Group 3 (Chascanum-Eragrostis racemosa Sandy Bankenveld) and Group 4 (Chascanum-Anthephora pubescens Sandy Bankenveld).

These two Groups are discussed together as they are split at the low H.S. $\chi^{2}$ level of 18,1 . The homogeneity of each Group is indicated by neither's being further subdivided until H.S. $\chi^{2} 9,5$. The combined Group, 3 and 4 , is also homogeneous, being maintained as a Group from H.S. $\chi^{2}=38,6$ to H.S. $\chi^{2}=18,1$. Thus, as a combined Group and as separate entities, Groups 3 and 4 are relatively homogeneous.

Quadrats belonging to both Groups occur along the western boundary of the area, in a round patch in the north-west, and the few other samples occur scattered through the remainder of the sampled area. Quadrats of both Groups occur together at each locality. Group 4 is the larger of the two and the usual pattern is for a quadrat of Group 3 to occur among a cluster of Group 4 quadrats.

Groups 3 and 4 form a clear ecological nodum associated with a thin, sandy overburden to dolomite. In the majority of quadrats, soil is shallow $(5-10 \mathrm{~cm})$, but is occasionally over one metre deep. In most quadrats, the soil surface is free of rock, or contains only scattered, small, chert fragments. It is possible that aeolian sand of Kalahari origin has blown from the west onto the edge of the area, forming a thin veneer over dolomite. Such a movement of sand would be in agreement with the views of Harmse (1967). Within the study area, wind-blown sand has collected in sink-holes and other depressions to form a similar habitat. In Group 4, four quadrats are located in local depressions while a number of quadrats from both Groups occur on flat plains or crests of rises on which sand could easily accumulate. A remarkable feature is, however, that over half the quadrats in Group 3 and over a third of the quadrats in both Groups occur on slightly sloping ground where it would be expected that erosion of sand would be greatest and accumulation least. As the rainfall is relatively low and run-off in the dolomite minimal, sand deposited on a slope is, however, not transported easily. Soil $\mathrm{pH}$ is about 6,5 in both Groups. Moderate to moderate-heavy grazing was found in most quadrats of both Groups. When light grazing was recorded, another disturbance factor, like proximity to diamond diggings, was usually noted. Mean number of species per quadrat in Groups
3 and 4 were 46,6 and 41,0 , respectively. The tall grass stratum was 60 to $75 \mathrm{~cm}$ high in both Groups, with a maximum of $90 \mathrm{~cm}$ in Group 3. The short grass stratum was 10 to $30 \mathrm{~cm}$ high in Group 3 and 10 to $20 \mathrm{~cm}$ high in Group 4. Total basal cover of both Groups was low (Table 5). Species present in over 19,9 percent of the quadrats of Groups 3 and 4 are given in Tables 5 and 6. Many species are common to both Groups and about eight species are found particularly in one or other of the two Groups.

\section{(d) Group 5 (Corchorus-Ursinia Bankenveld of} Disturbed Sites)

The secondary nature of the vegetation in the quadrats of this Group brought them together on the hierarchy. Some of the quadrats are laid out near diamond diggings, others on abandoned lands and the rest on heavily trampled and overgrazed vegetation. Quadrats of this small Group are scattered through the study area.

Many physiographic combinations are represented. Some quadrats are on crests of rises, some in hollows and some in intermediate positions. North- and southfacing aspects, as well as level sites, are found. Soils are usually shallow, being, in general, from two to eight $\mathrm{cm}$ deep and often being gravelly where occurring in fossil river courses. Deeper soil is found occasionally, the deepest for this Group being recorded as $0,5 \mathrm{~m}$. Mean number of species per quadrat was 40,0 . Total basal cover averaged 10,6 percent, only 2,8 percent of which was accounted for by the tall grass stratum (usually $60 \mathrm{~cm}$ tall but occasionally $90 \mathrm{~cm}$ tall). The low total cover and large percentage thereof accounted for by the short grass stratum (15 to $25 \mathrm{~cm}$ high) is a further indication of the disturbed nature of the vegetation. Species present in over 19,9 percent of the quadrats of Group 5 are given in Tables 5 and 6 .

Group 5 represents areas of disturbed vegetation within the study area. Thus, the areas next to abandoned diamond diggings belong to this Group, even though few quadrats were located there. The influence on the vegetation surrounding the diggings of over 100000 people (Williams, 1930) who flocked to the diamond fields from 1926 to 1929 must have been great and it is unlikely that the vegetation has fully recovered yet.
Fig. 14.-Graves of diamond miners in typical Bankenveld vegetation with abandoned diamond diggings on ridge in background. Grass in flower is Themeda triandra. Bakerville, Lichtenburg District.

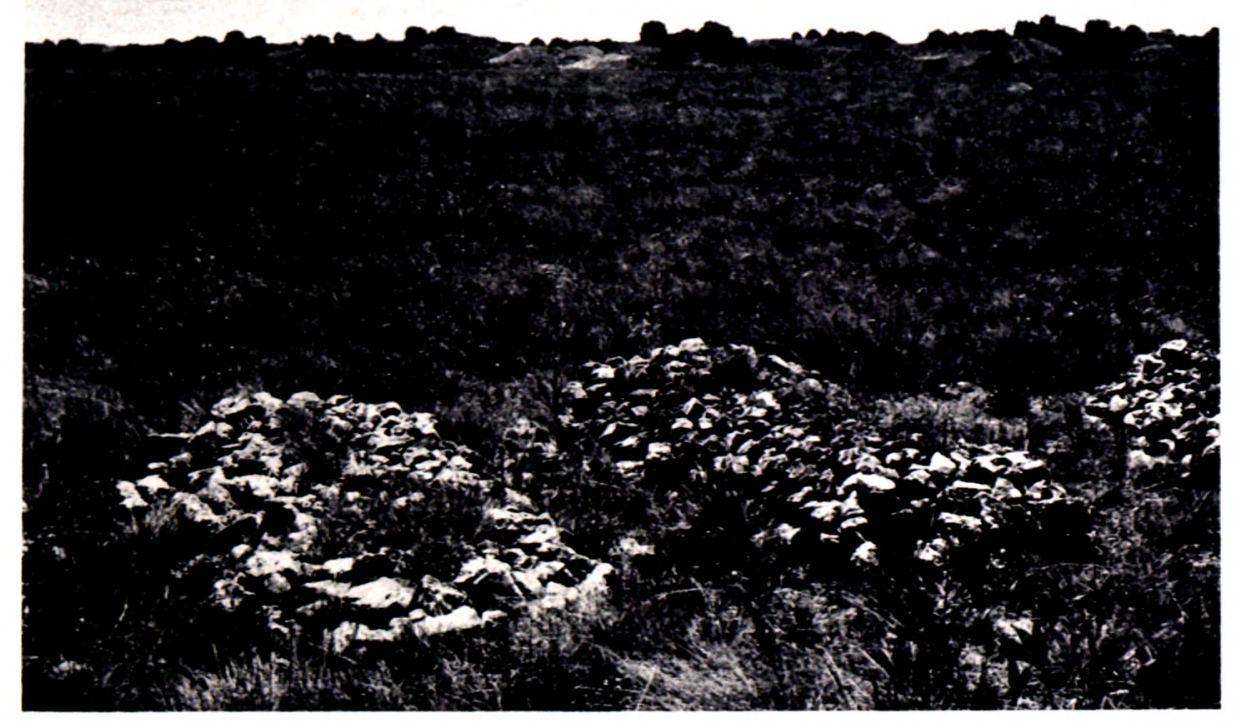


(e) Group 6 (Fingerhuthia-Oropetium Bankenveld of Dolomite Sheets)

With the exception of three quadrats, which occur scattered through the study area, the quadrats of this Group occur to the immediate north of Lichtenburg, in the southern-most part of the Bankenveld Land System.

Quadrats of this Group occur on extensive plains, in slight hollows and on gentle slopes near crests of plains. Quadrats are found on shallow soils where solid dolomite sheets are exposed on the surface. Soil, if it is present, is usually only 2 to $5 \mathrm{~cm}$ deep. Soil pH is usually 7,0 to 7,5 , in other words, slightly more alkaline than in most other groups. In three quadrats a slight soil $\mathrm{HCl}$ reaction was recorded. Grazing in seven quadrats was light and the vegetation appeared undisturbed. In the other five quadrats of the Group, grazing was moderately-heavy to heavy. Average total basal cover was just under 10 percent, with approximately equal contributions from the tall (usually 75 $\mathrm{cm}$, but ranging from 60 to $120 \mathrm{~cm}$ in height) and short (either 10 to $15 \mathrm{~cm}$ or 30 to $45 \mathrm{~cm}$ tall) grass strata. The mean number of species per quadrat was low $(36,5)$ but the standard deviation of the mean was high $(\mathrm{SD}=$ $7,4)$, indicating that while some quadrats were very poor in species, others were rich. Species present in over 19,9 percent of the quadrats of Group 6 are given in Tables 5 and 6.

The Group is named after Oropetium capense, a diminutive grass found in every quadrat of this Group. Gaff (1971) reported that $O$. capense could withstand virtually complete desiccation, a necessary prerequisite for survival on rock sheets with little soil as found in quadrats of this Group.

FIG. 15.-Spoil heaps from abandoned diamond diggings in Corchorus-Ursinia Bankenveld of Disturbed Sites. Bakerville, Lichtenburg District.
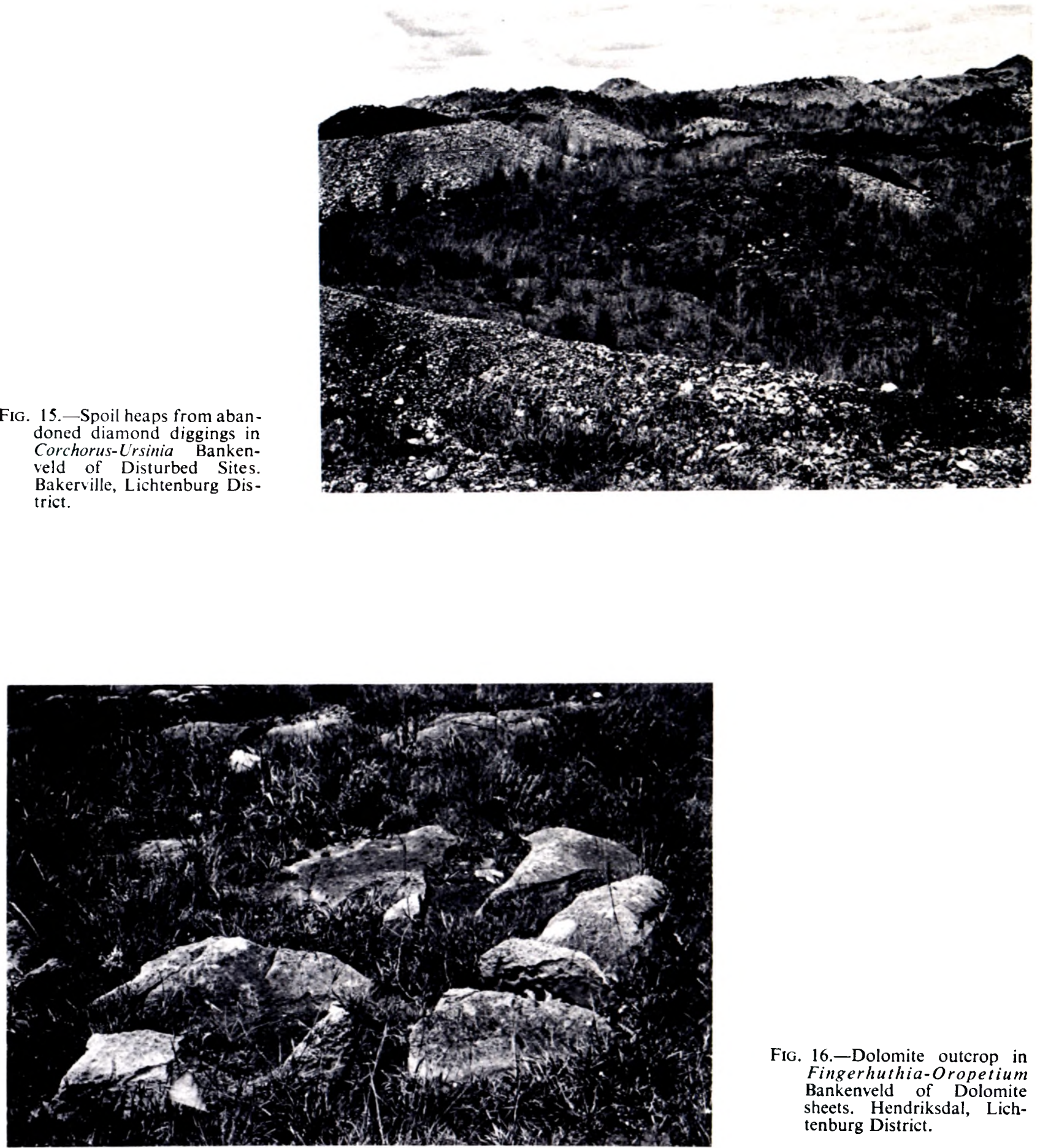

FIG. 16.-Dolomite outcrop in Fingerhuthia-Oropetium Bankenveld of Dolomite sheets. Hendriksdal, Lichtenburg District. 


\section{DISCUSSION AND CONCLUSIONS}

\subsection{Sampling strategy}

It is well documented that strictly systematic and random sampling, although deemed statistically justifiable and even preferable, are inefficient (Taylor, 1969; Werger, 1973). This is chiefly because such strategies result in the inclusion of narrow ecotones in collections of samples, which are then heterogeneous (Grunow, 1965a; Lambert, 1972). It also leads to undersampling generally-recognised but small vegetation units, such as vleis (marshes) and dolerite dyke communities, and over-sampling of large units. Small vegetation units might then not be identified by a statistical method, such as association analysis, which is programmed to terminate at a certain minimum number of samples. Even a group of two or three samples will, of course, be identified by association analysis if its constituent quadrats are sufficiently similar to each other and sufficiently different from other quadrats.

In a vegetation survey such as the present one, more interest is vested in dominant vegetation communities than in narrow ecotones and vegetation units of small area, while areas of intermediate size should be adequately sampled to enable identification and characterisation by the statistical process used. The stratified sampling strategy used for this study ensured that a representative sample of the variation was obtained (see also Werger, 1973), while the random element ensured that the sampling was statistically acceptable. Such a strategy is of particular importance where the number of samples is strictly limited, as it was in this study.

It is preferable to establish optimum sample size in the study area instead of using a size derived elsewhere (Lambert, 1972). In this study, it was considered that compatibility between studies was of greater importance than the derivation of a unique size for this project. Furthermore, results of pilot studies showed that a slightly smaller sample $\left(12 \mathrm{~m}^{2}\right)$ would have been adequate and $16 \mathrm{~m}^{2}$ was considered large enough to be a 'safe' minimum size for the entire Highveld Ecological Survey (J. C. Scheepers: pers. comm.).

Extensive cultivation in the CT Grassland Land System made sampling difficult. Not only are clusters of samples situated far apart, but great difficulty was experienced in getting samples representative of all vegetation types which were presumed to have existed in the area previously. Some types have almost certainly disappeared completely. As it is vegetation on soils that are less suitable for cultivation which remains, a marked sampling bias towards vegetation on these soils and away from that on soil suitable for cultivation is likely to have taken place.

The number of samples in both Land Systems is small. In CT Grassland there was the physical problem of fitting samples into a restricted area of natural vegetation while in Bankenveld it was considered that the major vegetation types had been adequately sampled by 110 samples. The limited period for fieldwork during the present study also affected the number of samples which could be taken.

There were two reasons for the small number of habitat variables recorded at each site. Firstly, as the study was conceived as a semi-detailed survey of short duration, intensive study of ecological interrelationships was not planned. Secondly, the number of habitat factors which can be studied in Bankenveld is limited by the nature of the soil. In many places, sheets of dolomite are exposed at the surface and the plants are rooted between rocks. Measurement of field capacity, wilting point, and similar measures are difficult as a result.

\subsection{Methodological aspects}

The broad differences between Bankenveld and CT Grassland Land Systems, outlined in section 1.7, are shown to be supported by quantitative analysis of the vegetation. The Total association analysis separated most quadrats laid out in Bankenveld from those laid out in CT Grassland. Nineteen Bankenveld quadrats occurred in groups consisting mainly of CT Grassland quadrats but Bankenveld groups never included CT Grassland quadrats. It was therefore concluded that certain Bankenveld vegetation quadrats resembled vegetation of CT Grassland groups in their floristic composition, but that no CT Grassland samples resembled Bankenveld groups. Of Bankenveld quadrats classified with CT Grassland groups, 42 percent were from Group 7 of the Bankenveld hierarchy and 37 percent were from Group 6 of the same classification. Group 7, the last group of the Bankenveld classification, was found to be a heterogeneous group of quadrats. The species composition of many Group 7 quadrats could be such that, by chance, they did not contain the dividing species necessary to include them in a group in which they would have been appropriate. In the Total analysis also, these quadrats were shown to be a heterogeneous collection by their being scattered through a number of final groups.

Apart from strong, positive species associations within quadrats of each Land System and negative associations between them, floristic richness may be partly responsible for the major automatic division between Bankenveld and CT Grassland. A floristically-rich group of quadrats is defined as one with a relatively high mean number of species within each quadrat of the group and a floristically-poor group is the converse. That floristic richness of quadrats may influence the nature of the resulting hierarchy was noticed on inspection of the mean numbers of species per quadrat in each final group of both hierarchies. In the Bankenveld classification, the mean decreases steadily from Group $1(49,5)$ and Group $2(43,6)$ to Groups $6(36,5)$ and $7(32,9)$, across the hierarchy from left to right. Thus, floristically-rich groups split off first and floristically-poor quadrats generally remain until last. Although evidence is not available, it is conceivable that more positive species associations are present in floristically-rich collestions of quadrats, making the collections more homogeneous and therefore more likely to be split off. A similar decrease from left to right in mean number of species per quadrat was found in the Total analysis. The overall mean number of species per quadrat is, however, much lower. The overall average in the 110 Bankenveld quadrats exceeds 40. In CT Grassland Groups 4b, 5b, 6 and 7a, which contain most species per quadrat, the mean is less than 27. The average decreases steadily to the last Group, 9c, with a mean of 15,2 . Thus, if floristic richness is a factor controlling the results of the classification, the marked division between Bankenveld and CT Grassland Land Systems would be expected. It is also the possible explanation for floristicallypoor Bankenveld quadrats of Groups 6 and 7 occurring with floristically-poor CT Grassland groups in the Total analysis.

To obtain the greatest amount of information from the association analyses they had to be interpreted at more than one stopping level. A single stopping rule, as initially proposed by Williams \& Lambert (1959, 1960), was not adequate. It is considered. furthermore, that experience with use of the method greatly improves the result that is obtained. Association analysis should be considered as an aid in the study of vegetation and not as a tool to be applied by technicians with no training in its use and misuse. 
Although a few quadrats could not be successfully re-allocated, the use of species recorded around the edge of the quadrat to re-allocate quadrats was successful. Had total floristic composition also been taken into account in the re-allocation procedure and not only habitat features and species in the surrounds of quadrats, an even more successful re-allocation may have been realized.

Indicator values were of use for determining significance levels for species occurring more commonly inside a group than outside it. Used in conjunction with positive and negative dividing species and coverabundance estimates, Indicator values enabled good floristic definitions of groups to be made. On the other hand, negative Indicator values, given to species occurring more frequently outside a group than inside it, were of limited use (see Morris, 1973).

Although no objective criteria for measuring success are known, it may be concluded that the technique of association analysis performed adequately in providing a generally interpretable classification of the vegetation. A perfect classification of a data set of this size probably does not exist and the utility of a particular strategy as an aid for the study of the vegetation should be the criterion on which the classification is judged.

\subsection{Vegetational aspects}

In the Total association analysis, division between Bankenveld and CT Grassland quadrats is fairly clear. As the Bankenveld area was considered most important from a vegetational point of view and as there was some mixture of Bankenveld quadrats in groups of predominantly CT Grassland quadrats, a separate analysis of the 110 Bankenveld Land System quadrats was undertaken. It was not considered profitable to interpret Bankenveld final groups in both the Total analysis and the Bankenveld analysis. In a general way, results of the Bankenveld analysis and Bankenveld part of the Total analysis are similar.

In CT Grassland, eleven final groups are recognised and described. Two final groups, Short and Tall Stipagrostis uniplumis Calcareous Grassland. occur on soils overlying surface limestone deposits with the same geomorphology and soil series. Soils are generally slightly deeper and basal cover of tall grasses is double in quadrats classified as Tall Grassland in comparison with quadrats of Short Grassland. In both Groups grazing is usually light. The community is found around Lichtenburg and in a belt extending west of the town.

Another two final groups. Elionurus argenteus Secondary Grassland and E. argenteus Primary Grassland, occur on rocks of the Ventersdorp system. Heavy grazing and soil erosion are often recorded from quadrats of the former while the vegetation is usually in good condition in the latter Group. Most Eliomurus argenteus Grassland is found south-west of Lichtenburg.

Two final groups also occur on Dwyka tillite substrate. They are $C 1$ mbopogon plurinodis Grassland and Secondary Cymbopogon plurinodis Grassland. The difference between these two Groups is also in degree of biotic influence but, as there are only three quadrats in the latter Group, the distinction does not carry much weight.

Three final groups, Acacia karroo Savanna, Acacia karroo Open Woodland and Drainage Basin Acacia karroo Open Woodland are found on the mediumand poorly-drained soils of the area. Heavy grazing and trampling are usual in quadrats of these Groups. Most quadrats are situated on Ventersdorp Series rocks. In all three Groups a woody element is present with Acacia karroo as the dominant tree and shrub species.

It is concluded from the description given that the major vegetational differences in the CT Grassland Land System can be related to the geological substrate and gross soil characteristics. Within major groups, management is often an important factor although, in some cases, there are not enough quadrats in a group for even a reasonable degree of certainty. Two final groups, one of only three quadrats, from adjacent legs of the hierarchy could not be interpreted.

In the Bankenveld association analysis ten final groups are distinguished. For discussion, the four final groups of Group 2 are lumped and Groups 3 and 4 are also lumped. Suggested relationships between Bankenveld groups are indicated in Fig. 17.

It is considered that Group 2 (DiheteropogonSchizachyrium Bankenveld) is the typical vegetation of the Bankenveld Land System. Group 1 (Diheteropogon-Stipagrostis Primary Bankenveld) consists of quadrats laid out in vegetation that had been well managed. Group 1 is closely related to Group 2 but has experienced less selective or heavy grazing and trampling in the past. It may be considered as the "climax' vegetation type, although it possibly occurs in a slightly different habitat.

Quadrats of Groups 3 and 4 (Chascanum-Eragrostis racemosa Sandy Bankenveld and Chascamum-Anthephora pubescens Sandy B .nkenveld) occur together on the western edge oi the Bankenveld Land System and in a circular patch in the north-west of the study area. Differences between the two Groups are not clear. Both are found where sand overlies dolomite. It is suggested that aeolian sand has been blown from the west over the dolomite and provided the habitat for these Groups.

Past distu bance in the area was discussed earlier. It is suggested that quadrats of Group 5 (CorchorusUrsinia Bankenveld of Disturbed Sites) are those in vegetation which has been disturbed in the past.

Exposed sheets of dolomite are characteristic of parts of Bankenveld, particularly in the area to the immediate north of Lichtenburg. Group 6 (Fingerhuthia-Oropetium Bankenveld of Dolomite Sheets) is the vegetation typical of such areas.

\section{ACKNOWLEDGEMENTS}

Prof. J. O. Grunow of the Department of Plant Production, University of Pretoria is thanked, as co-promoter, for his interest in this project, for his most helpful suggestions during the preparation of the thesis on which this paper is based and also for reading this manuscript. I thank Dr D. Edwards and my colleagues, of the Botanical Survey Section of the B tanical Research Institute, for support and encouragement during the execution of this project. In particular, I am grateful to Dr M. J. A. Werger for fruitful discussions, leading to many improvements in this account and to Dr J. C. Scheepers for his co-operation in the planning of this part of the Highveld Region Survey. For assistance in the field I thank Messrs C. Boucher, D. Müller and G. J. Engelbrecht. $\mathrm{Mr}$ B. J. Coetzee kindly assisted me with the construction of Table 4. Mrs E. van Hoepen and her staff at the National Herbarium named the plants collected from the area. Dr E. Verster of the Soils and Irrigation Research Institute kindly gave me the most recent soil classification system applicable to the area. The Extension Officer, Department of Agricultural Technical Services, Lichtenburg, is thanked for the facilities of his office, which were put at my disposal during field work. 
FIG. 17.--Suggested relationships between Bankenveld association analysis groups.

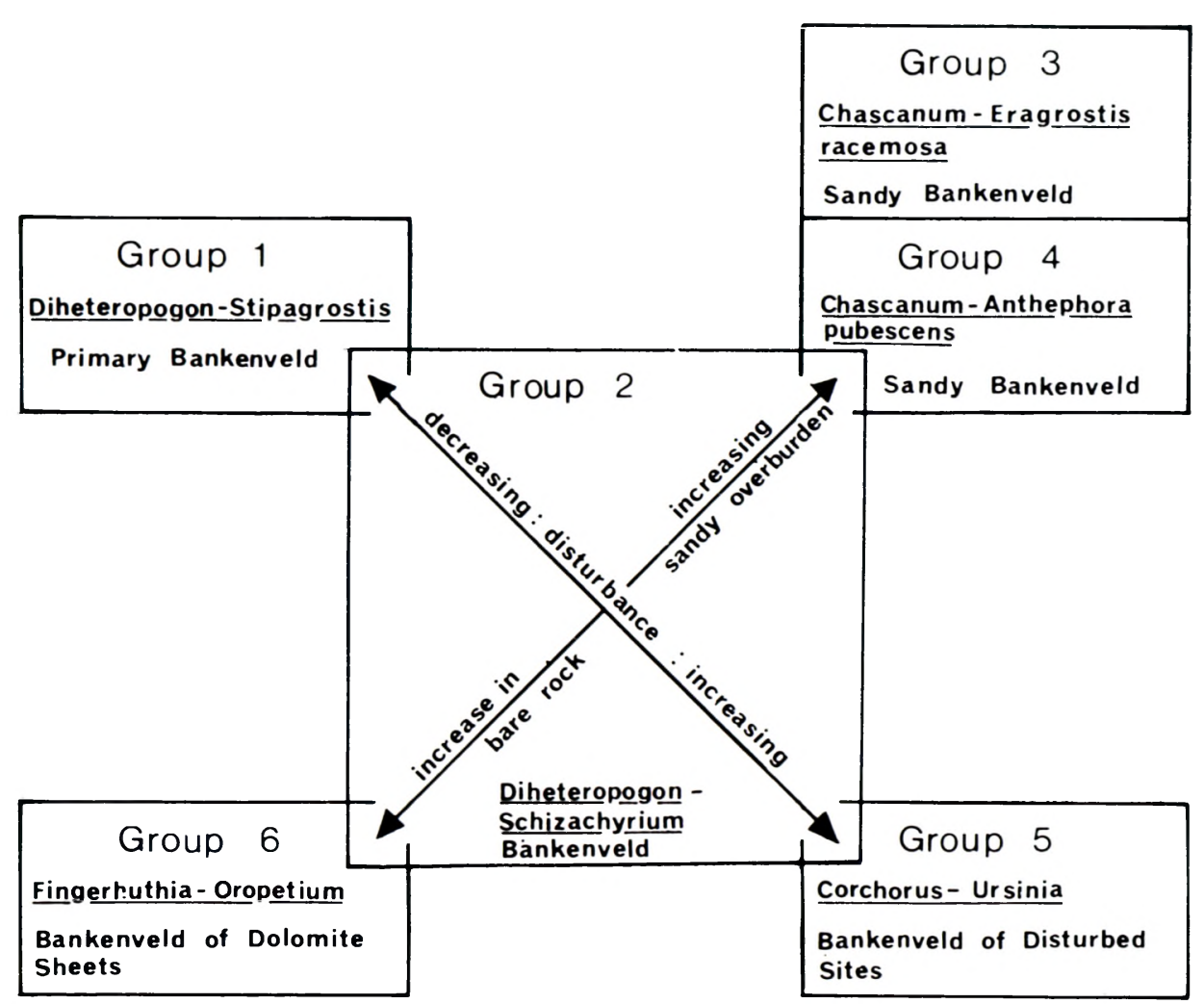

\section{UITTREKSEL}

'n Kwantitatiewe, semi-gedetaileerde plantekologiesestudie is gedoen vir die gebied tussen $25^{\circ} 54^{\prime}$ en $26^{\circ} 22^{\prime}$ 0 en $26^{\circ} 00^{\prime}$ en $26^{\circ} 20^{\prime} S$, geleë rondom Lichtenburg in suidwes-Transvaal. Die gemiddelde jaarlikse temperatuur van hierdie studiegebied is $17^{\circ} \mathrm{C}$ en die jaarlikse reenval is omtrent $600 \mathrm{~mm}$. 'n Basiese verskil kan waargeneem word tussen die Bankenveld Land Sisteem en die CT Grasveld Land Sisteem. Eersgenoemde het 'n onderlaag van dolomiet met litosoliese grond, Bankenveld plantegroei en veeboerdery as vernaamste bodembenutting. In teenstelling daarmee het laasgenoemde ' $n$ onderlaag van graniet, Ventersdorp lavas, Dwyka kleileem (tillite) en oppervlakkalksteen met Shorrocks, Mangano en Lichtenburg grondseries, Cymbopogon-Themeda Veld plantegroei en ekstensiewe mielieboerdery as hoof bodembenutting. Een honderd en tien $16 \mathrm{~m}^{2} \mathrm{kwadrate}$ is geplaas in elke land sisteem deur middel van gestratifiseerde ewekansige monstering. Van die 247 spesies wat teegekom is, het amper ' $n$ honderd in minder as $6 \mathrm{kwadrate}$ voorgekom. Themeda triandra, Aristida congesta, Elionurus argenteus, Anthospermum rigidum en Justicia anagaloides het deurgaans baie algemeen voorgekom. Twee assosiasie-analises is gedoen en 15 finale groepe is geïnterpreteer vanuit'n totaal van 21 groepe.

\section{REFERENCES}

Acocks, J. P. H., 1953. Veld types of South Africa. Mem. Bot. Surv. S. Afr. 28: 1-192

Acocks, J. P. H., 1975. Veld types of South Africa. Second edition. Mem. Bot. Surv. S. Afr. 40: 1-128.

Boucher, C., 1972. The vegetation of the Cape Hangklip Area. Unpublished M.Sc. thesis, University of Cape Town

Coetzee, B. J., 1972 'n Plantsosiologiese studie van die Jack Scottnatuurreservaat. Unpublished M.Sc. thesis, University of Pretoria.

DowLING, J. W. F., 1968. Land evaluation for engineering purposes in Northern Nigeria pp. 147-159. In G. A. Stewart (ed.), Land evaluation. Melbourne: Macmillan.

DownING,B. H., 1966. The plant ecology of Tabamhlope Vlei, Natal. Unpublished M.Sc. thesis, University of Natal.

Downing, B. H., 1972. A plant ecological survey of the Umfolozi Game Reserve, Zululand. Unpublished Ph.D thesis, University of Natal.
DraPer, D., 1928. On the occurrence of diamonds associated with the chert beds of the dolomite series in the Districts of Ventersdorp and Lichtenburg. Trans. Geol. Soc. S. Afi. 30: $57-67$.

Du Toit, A. L., 1951. The diamondiferous gravels of Lichtenburg. Mem. Geol. Surv. 44.

GaFF, D. F., 1971. Desiccation-tolerant flowering plants in Southern Africa. Science 174: 1033-1034.

Goodall, D. W., 1953. Objective methods for the classification of vegetation. II. Fidelity and indicator value. Aust. J. Bot. $1: 434-456$

Grunow, J. O. 1959. Rapid rotational grazing system most effective on sour veld. Fing in S. Afr. 352: 40 41 .

Grunow, J. O., 1965a. Objective classification of plant communities: a synecological study in the sour-mixed bushveld of Transvaal. Unpublished D.Sc. (Agric.) thesis, University of Pretoria.

Grunow, J. O., 1965b. Objective classification of plant communities: a synecological study in the sour-mixed bushveld of Transvaal. S. Afr. J. Agric. Sci. 7: 171-172.

Grunow, J. O., 1967. Objective classification of plant communities: a synecological study in the sourish mixed bushveld of Transvaal. J. Ecol. 55:691-710.

Grunow, J. O. \& LANCE, G. N., 1969. Classification of savanna by information-analysis. S. Afr. J. Sci. 65: 341-348.

HARMSE, H. J. Von M., 1967. Soil genesis in the Highveld Region, South Africa. Unpublished D.Sc. thesis, University of Utrecht.

LAMBERT, J. M., 1972. Theoretical models for large-scale vegetation survey. In J. N. R. Jeffers (ed.), Mathematical models in ecologv, 87-109. Oxford: Blackwells.

Lambert, J. M. \& Williams, W. T., 1962. Multivariate methods in plant ecology. IV. Nodal analysis. J. Ecol. 50: 775-802.

Mabbutt, J. A., 1968. Review of concepts of land classification. In G. A. Stewart (ed.), Land evaluation, pp 11-28. Melbourne: Macmillan.

Miller, P. M., 1966. An objective delineation of plant communities in a selected area of grassland vegetation. Unpublished M.Sc. (Agric.) thesis, University of Natal.

Miller, P. M. \& Booysen, P. DE V., 1968. The delineation of plant communities in relatively homogeneous grassland. Proc. Grassld. Soc. Sth. Afr. 3:43-50.

Morris, J. W., 1973. Automatic classification and ecological profiles of South-nestern Transvaal Highveld Grassland. Unpublished Ph.D. thesis, University of Natal.

RoBerts, B. R., 1966. The ecology of Thaba 'Nchu-A statistical study of vegetation habitat relationships. Unpublished Ph.D. (Agric.) thesis, University of Natal.

SCheEPers, J. C., 1969. A preliminary assessment of associationanalysis in the Kroonstad area. Proc. Grassld. Soc. Sth. Afr. 4: 78-83. 
SCHEFPERS, J. C., 1975. The plant ecology' of the Kroonstad and Bethlehem areas of the Highveld Agricultural Region. Unpublished D.Sc. thesis, University of Pretoria.

Schulze, B. R. 1947. The climates of South Africa according to the classifications of Köppen and Thornthwaite. S. Afr. Geogr. J. 29: 32-42.

SchulzE, B. R., 1958. The climate of South Africa according to Thornthwaite's rational classification. S. Afr. Geogr. J. 40: $31-53$

Schulze, B. R., 1965. Climate of South Africa. Part 8. Genercl Survey. Pretoria: Weather Bureau.

TAYLOR, H. C. 1969. A vegetation survey of the Cape of Good Hope Nature Reserve. Unpublished M.Sc. thesis, University of Cape Town.

UNESCO-FAO, 1963. Bioclimatic map of the Mediterranean Zone. Ecological study of the Mediterranean Zone. Explanatory notes. Arit Zone Res. 21: 1-58.

VAN DER BANK, W. J., 1968. Bodemopname van Lichtenburg. Pretoria: Navorsingsinstituut vir Grond.

VAN DER WALT, J. L., 1962. Ondersoek na 'n objektiewe metode van plantopname in die Sneeubergreeks. Unpublished M.Sc. (Agric.) thesis, University of Pretoria.

Von Backström, J. W., Schumanx, F. W., Le Roux, H. D., KENT, L. E., \& DU TOIT, A. L., 1953. The geology of the area ciround Lichtenburg. Pretoria: Geological Survey.

WAGNer, P. A., 1914. The diamond fields of Southern Africa. Johannesburg: Transvaal Leader.
Walter, H. \& Leith, H., 1960. Klimadiagram-Weltatlas. Jena: Fisher.

Weather Bureau, 1954. Climate of South Africa. Part 1. Climate statistics. Pretoria: Weather Bureau.

Weather Bureau, 1965. Climate of South Africa. Part 9. Average monthly rainfall up to the end of 1960. Pretoria: Weather Bureau.

Weather Bureau, 1968. Solar radiation and sumshine. Pretoria: Weather Bureau.

Werger. M. J. A., 1973. Phytosociology of the Upper Orange River Vallev', South Africa. A strntaxonomical and synecological study. Unpublished D.Sc. thesis, University of Nijmegen.

WiLliams, A. F., 1930. Diamond-bearing alluvial gravels of the Union of South Africa. Brit. Emp. Min. Metall. Congr. Handb. 1-169.

Williams, W. T. \& LamberT, J. M., 1959. Multivariate methods in plant ecology. I. Association-analysis in plant communities. J. Ecol. 47: 83-101.

Williams, W. T. \& LAMBERT, J. M., 1960. Multivariate methods in plant ecology. II. The use of an electronic digital computer for association-analysis. J. Ecol. 48: 689-710.

Williams, W. T. \& LaMBeRT, J. M., 1961. Multivariate methods in plant ecology. III. Inverse association-analysis. J. Ecol. 49: 717-729.

Williams, W. T. \& LaNce, G. N., 1958. Automatic subdivision of associated populations. Nature, Lond. 182: 1755. 